\title{
Intermetallic Growth and Interfacial Properties of the Grain Refiners in Al Alloys
}

\author{
Chunmei Li *, Nanpu Cheng, Zhiqian Chen, Zhongjing Xie and Liangliang Hui \\ Faculty of Materials and Energy, Southwest University, Chongqing 400715, China; \\ cheng_np@swu.edu.cn (N.C.); chen_zq@swu.edu.cn (Z.C); xzjlms13@email.swu.edu.cn (Z.X); \\ hl10237@email.swu.edu.cn (L.H.) \\ * Correspondence: lcm1998@swu.edu.cn
}

Received: 13 February 2018; Accepted: 17 April 2018; Published: 20 April 2018

\begin{abstract}
Al}_{3} \mathrm{TM}(\mathrm{TM}=\mathrm{Ti}, \mathrm{Zr}, \mathrm{Hf}, \mathrm{Sc})$ particles acting as effective grain refiners for $\mathrm{Al}$ alloys have been receiving extensive attention these days. In order to judge their nucleation behaviors, first-principles calculations are used to investigate their intermetallic and interfacial properties. Based on energy analysis, $\mathrm{Al}_{3} \mathrm{Zr}$ and $\mathrm{Al}_{3} \mathrm{Sc}$ are more suitable for use as grain refiners than the other two intermetallic compounds. Interfacial properties show that $\mathrm{Al} / \mathrm{Al}_{3} \mathrm{TM}(\mathrm{TM}=\mathrm{Ti}, \mathrm{Zr}, \mathrm{Hf}, \mathrm{Sc})$ interfaces in I-ter interfacial mode exhibit better interface wetting effects due to larger Griffith rupture work and a smaller interface energy. Among these, $\mathrm{Al} / \mathrm{Al}_{3} \mathrm{Sc}$ achieves the lowest interfacial energy, which shows that $\mathrm{Sc}$ atoms should get priority for occupying interfacial sites. Additionally, Sc-doped $\mathrm{Al} / \mathrm{Al}_{3}(\mathrm{Zr}, \mathrm{Sc})$ interfacial properties show that $\mathrm{Sc}$ can effectively improve the $\mathrm{Al} / \mathrm{Al}_{3}(\mathrm{Zr}, \mathrm{Sc})$ binding strength with the $\mathrm{Al}$ matrix. By combining the characteristics of interfaces with the properties of intermetallics, the core-shell structure with $\mathrm{Al}_{3} \mathrm{Zr}$-core or $\mathrm{Al}_{3} \mathrm{Zr}(\mathrm{Sc} 1-1)$-core encircled with an Sc-rich shell forms.
\end{abstract}

Keywords: intermetallics; interface; first-principles; elastic properties; Griffith rupture work

\section{Introduction}

Experimental studies [1,2] have repeatedly shown that $\mathrm{Al}_{3} \mathrm{Ti}$ and $\mathrm{Al}_{3} \mathrm{Zr}$ particles act as the heterogeneous nuclei and dramatically refine the grains of the $\alpha$-Al matrix. Recent investigations indicate that $\mathrm{Al}_{3} \mathrm{Sc}$ and $\mathrm{Al}_{3}(\mathrm{Zr}, \mathrm{Sc})$ are also perfect substitutions as grain refiners for $\mathrm{Al}-\mathrm{Zn}-\mathrm{Mg}$ alloys [3-5]. A fine-grained Al-6.10\%Mg- $0.30 \% \mathrm{Mn} 610.25 \% \mathrm{Sc}-0.1 \% \mathrm{Zr}$ (wt \%) alloy [3] shows superior superplastic behavior while subjecting the asymmetrical rolling, which can be ascribed to the fine (sub)grains which may slow down the rate of cavity growth and the stable coherent $\mathrm{Al}_{3}\left(\mathrm{Sc}_{1-\mathrm{x}} \mathrm{Zr}_{\mathrm{x}}\right)$ nano-particles that can ensure a good stability of the fine-grained structure during superplastic deformation. Additionally, in the Al-5.70Zn- $1.98 \mathrm{Mg}-0.35 \mathrm{Cu}-0.25 \mathrm{Sc}-0.10 \mathrm{Zr}$ alloy [4], $\mathrm{Al}_{3}\left(\mathrm{Sc}_{1-\mathrm{x}} \mathrm{Zr}_{\mathrm{x}}\right)$ nano-particles play an important role in accelerating the cooperative grain boundary deformation and affect the dynamic softening deformation mechanism of Al- $\mathrm{Zn}-\mathrm{Mg}$ alloys. Besides, the $\mathrm{Sc}$ and $\mathrm{Zr}$ additions to the Al-Cu-Mg alloy [5] could strongly inhibit recrystallization, refine grain size, impede the segregation of the Cu element along the grain boundary, and increase the spacing of grain boundary precipitates. All these experimental results confirm the importance of refiners. However, choosing the optimized element for micro-alloying aimed at $\mathrm{Al}$ alloys' grain refinement and judging the nucleation behavior of $\mathrm{Al}_{3} \mathrm{TM}(\mathrm{TM}=\mathrm{Ti}, \mathrm{Zr}, \mathrm{Hf}, \mathrm{Sc})$ and $\mathrm{Al}_{3}(\mathrm{Zr}, \mathrm{Sc})$ in the $\mathrm{Al}$ matrix is clearly based on the intrinsic elastic and thermodynamic properties of the intermetallics of $\mathrm{Al}_{3} \mathrm{TM}(\mathrm{TM}=\mathrm{Ti}$, $\mathrm{Zr}, \mathrm{Hf}, \mathrm{Sc}$ ) and the interfacial properties of them joining with the Al matrix.

In view of the limitation of experimental techniques, the first-principles approach has been extensively adopted to investigate the properties of the strengthening intermetallics [6], such as 
$\mathrm{Al}_{3}\left(\mathrm{Ti}_{\mathrm{x}} \mathrm{V}_{1-\mathrm{x}}\right)$ [7], $\mathrm{Al}_{3} \mathrm{Zr}$ [8], and $\mathrm{Al}-\mathrm{TM}(\mathrm{TM}=\mathrm{Ti}, \mathrm{Zr}$, and $\mathrm{Hf})$ systems [9]. Besides the properties of the interfaces, precipitates with the $\mathrm{Al}$ matrix have also been studied to dissect the strengthening and toughening mechanisms of the precipitates in the matrix, such as the $\mathrm{Al} / \mathrm{Al}_{3} \mathrm{Ti}$ interface [10] and the $\mathrm{Al} / \mathrm{Al}_{3} \mathrm{Sc}$ [11] interface. Nevertheless, the energy and elastic properties of $\mathrm{Al}_{3} \mathrm{TM}(\mathrm{TM}=\mathrm{Ti}, \mathrm{Zr}, \mathrm{Sc})$ and $\mathrm{Al}_{3}(\mathrm{Zr}, \mathrm{Sc})$ phases, as well as the interfacial modes of them with the $\mathrm{Al}$ matrix, have not been systematically studied. Because of the pivotal significance of the grain refiners' properties in practical applications, we focus on the theoretical investigations of the intermetallics' properties. We target the interfacial properties between them and the $\mathrm{Al}$ matrix. These are done to determine the desirable component of the grain refiner and judge the preferable doping ratio of Sc atoms.

This paper consists of four parts. Section 2 describes the computational methods. Section 3 presents the formation enthalpies, elastic anisotropies, and electronic structures of $\mathrm{Al}_{3} \mathrm{TM}(\mathrm{TM}=\mathrm{Ti}, \mathrm{Zr}, \mathrm{Sc})$ and $\mathrm{Al}_{3}(\mathrm{Zr}, \mathrm{Sc})$ intermetallics, with the interfacial properties of $\mathrm{Al} / \mathrm{Al}_{3}(\mathrm{Zr}$, Sc). Finally, Section 4 provides a brief summary and conclusion of this paper. The accuracy of our first-principles calculations is assessed by comparing the theoretical calculation results with the experimental values for lattice parameters, elastic properties, and formation energies.

\section{Method and Models of Calculation}

\subsection{Models Construction}

In this study, $\mathrm{Al}_{3} \mathrm{TM}(\mathrm{TM}=\mathrm{Ti}, \mathrm{Zr}, \mathrm{Hf}, \mathrm{Sc})$ and $\mathrm{Al}_{3}(\mathrm{Zr}, \mathrm{Sc})$ phases combined with the interfaces of the Al matrix have been investigated by using the first-principles method on the basis of the DFT plane-wave method [6]. Figure $1 \mathrm{a}, \mathrm{b}$ shows the unit cell of $\mathrm{Al}_{3} \mathrm{TM}(\mathrm{TM}=\mathrm{Ti}, \mathrm{Zr}, \mathrm{Hf}, \mathrm{Sc})$ phases, where Figure $1 \mathrm{a}$ is a polyherdral model for $\mathrm{Al}_{3} \mathrm{Zr}$, while Figure $1 \mathrm{~b}$ represents only the atomic site occupations. $\mathrm{Al}_{3} \mathrm{TM}(\mathrm{TM}=\mathrm{Ti}, \mathrm{Zr}, \mathrm{Hf}, \mathrm{Sc})$ phases all crystallize in the I4/MMM space group (No. 139) with a tetragonal crystal system and Al crystallizes in the FM-3M space group (No. 225) with a cubic crystal system. The corresponding lattice parameters, volumes of unit cells, crystal structures, and space groups are shown in Table 1 . The substitutional unit is modeled in a $2 \times 2 \times 1$ supercell with periodic boundary conditions, which is shown in Figure 1. In order to gain the efficient doping ratio of $\mathrm{Sc}$ in $\mathrm{Al}_{3} \mathrm{Zr}$, the doping ratio increases from $1 / 16$ to $15 / 16$. Series of models are built and calculated combining the doping ratio at the doping site. Based on these former calculations, the influence of the Sc-doping ratio on the crystal formation can be gained. Then, with the purpose of decreasing the quantity of the calculation, the smaller calculation units shown in Figure $1 \mathrm{c}-\mathrm{f}$ are built. Once again, the Sc-doping ratio and site are taken into account.

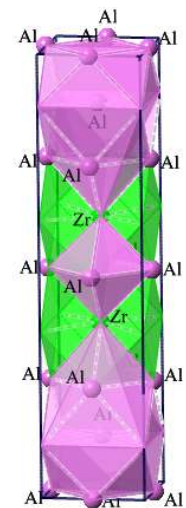

(a)

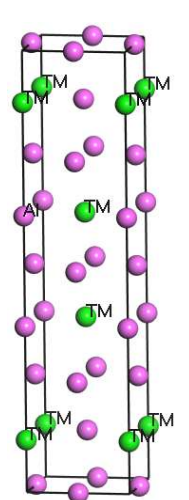

(b)

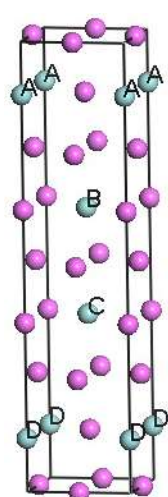

(c)

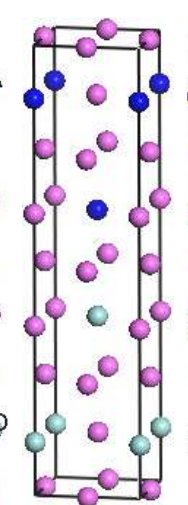

(d)

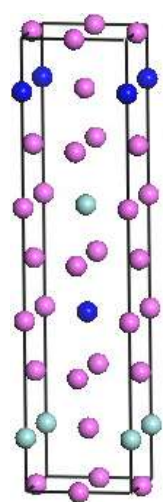

(e)

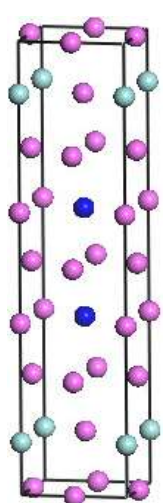

(f)

Figure 1. Crystal models. (a) Polyhedral model of $\mathrm{Al}_{3} \mathrm{Zr}$; (b) $\mathrm{Al}_{3} \mathrm{TM}(\mathrm{TM}=\mathrm{Ti}, \mathrm{Zr}, \mathrm{Hf}, \mathrm{Sc}$ ); (c) $\mathrm{Al}_{3} \mathrm{Zr}(\mathrm{Al}: \mathrm{Zr}=12: 4)$; (d) $\mathrm{Al}_{3} \mathrm{Zr}(\mathrm{Sc} 2-1)(\mathrm{Al}: \mathrm{Zr}: \mathrm{Sc}=12: 2: 2) ;\left(\right.$ e) $\mathrm{Al}_{3} \mathrm{Zr}(\mathrm{Sc} 2-2) \quad(\mathrm{Al}: \mathrm{Zr}: \mathrm{Sc}=12: 2: 2)$; (f) $\mathrm{Al}_{3} \mathrm{Zr}(\mathrm{Sc} 2-3)(\mathrm{Al}: \mathrm{Zr}: \mathrm{Sc}=12: 2: 2)$. 
Table 1. Lattice parameters of the calculated $\mathrm{Al}_{3} \mathrm{TM}(\mathrm{TM}=\mathrm{Ti}, \mathrm{Zr}, \mathrm{Hf}, \mathrm{Sc})$ phases.

\begin{tabular}{|c|c|c|c|c|c|c|c|c|c|c|c|c|c|c|c|}
\hline \multirow[b]{2}{*}{ Phases } & \multicolumn{3}{|c|}{$\mathrm{Al}$} & \multicolumn{3}{|c|}{$\mathrm{Al}_{3} \mathrm{Ti}$} & \multicolumn{3}{|c|}{$\mathrm{Al}_{3} \mathrm{Zr}$} & \multicolumn{3}{|c|}{$\mathrm{Al}_{3} \mathrm{Hf}$} & \multicolumn{3}{|c|}{$\mathrm{Al}_{3} \mathrm{Sc}$} \\
\hline & $\begin{array}{c}\text { Cal. [This } \\
\text { Work] }\end{array}$ & Cal. & Exp. & $\begin{array}{c}\text { Cal. [This } \\
\text { Work] }\end{array}$ & Cal. & Exp. & $\begin{array}{l}\text { Cal. [This } \\
\text { Work] }\end{array}$ & Cal. & Exp. & $\begin{array}{c}\text { Cal. [This } \\
\text { Work] }\end{array}$ & Cal. & Exp. & $\begin{array}{c}\text { Cal. [This } \\
\text { Work] }\end{array}$ & Cal. & Exp. \\
\hline Crystal System & Cubic & Cubic & Cubic & Tetragonal & Tetragonal & Tetragonal & Tetragonal & Tetragonal & Tetragonal & Tetragonal & Tetragonal & Tetragonal & Tetragonal & Tetragonal & Tetragonal \\
\hline Space Group & FM-3M & FM-3M & FM-3M & I4/MMM & I4/MMM & I4/MMM & I4/MMM & I4/MMM & I4/MMM & I4/MMM & I4/MMM & I4/MMM & I4/MMM & I4/MMM & I4/MMM \\
\hline $\begin{array}{c}a=b(\AA) \\
\text { (deviation) }\end{array}$ & 4.053 & 4.046 [12] & 4.049 [12] & $\begin{array}{c}3.907 \\
(-3.60 \%)\end{array}$ & $\begin{array}{l}3.885[13] \\
3.81[14]\end{array}$ & $3.89[15]$ & $\begin{array}{c}4.028 \\
(-0.62 \%)\end{array}$ & $\begin{array}{c}3.999[16] \\
4.008[17] \\
4.02[18]\end{array}$ & $\begin{array}{l}4.007[19] \\
3.999[20]\end{array}$ & $\begin{array}{c}4.004 \\
(-1.22 \%)\end{array}$ & $\begin{array}{l}3.990[17] \\
3.987 \text { [21] }\end{array}$ & $4.01[21]$ & $\begin{array}{c}4.055 \\
(0.04 \%)\end{array}$ & & \\
\hline$c(\AA)$ & 4.053 & 4.046 [12] & 4.049 [12] & 16.714 & $\begin{array}{l}16.823[13] \\
16.459[14]\end{array}$ & $16.922[15]$ & 17.384 & $\begin{array}{c}17.283[16] \\
17.297[17] \\
17.36[18] \\
\end{array}$ & $\begin{array}{l}17.286[19] \\
17.283[20]\end{array}$ & 17.224 & $\begin{array}{l}17.172[17] \\
17.179[21]\end{array}$ & 17.653 [21] & 17.283 & & \\
\hline $\mathrm{V}\left(\AA^{3}\right)$ & 66.59 & & & 255.18 & & & 282.10 & $276.43[16]$ & & 276.09 & & & 284.16 & & \\
\hline
\end{tabular}


Figure 2 shows the high-resolution transmission electron microscopy (HRTEM), together with the selected area electron diffraction (SAED) image of $\mathrm{Al}_{3} \mathrm{Zr}$ in the $\mathrm{Al}$ alloy at a solid-solution state. This experimental Al alloy (Al-Zn0.078-Mg0.018-Cu0.015-Zr0.001) (wt \%) was prepared by semi-continuous casting, and step-homogenized at $430{ }^{\circ} \mathrm{C}$ for $18 \mathrm{~h}$ and then at $467^{\circ} \mathrm{C}$ for $4 \mathrm{~h}$. After that, the homogenized sample was subjected to solution and quenching treatments. Based on the SAED image shown in Figure $2 \mathrm{c}$, it can be deduced that phase $\mathrm{Al}_{3} \mathrm{Zr}$ is coherent with the $\mathrm{Al}$ matrix, with its [1] and [010] crystallographic orientations parallel to [001] and [010] crystallographic orientations of the $\mathrm{Al}$ matrix. Combining the HRTEM image of $\mathrm{Al}_{3} \mathrm{Zr}$ precipitated in the $\mathrm{Al}$ matrix with other research results [6-9], it can be judged that the $\mathrm{Al}_{3} \mathrm{Zr}\{001\} / \mathrm{Al}\{001\}$ interface mode is one of the dominating interface modes of $\mathrm{Al}_{3} \mathrm{Zr}$ phase in the $\mathrm{Al}$ matrix. In addition, the diameter of the $\mathrm{Al}_{3} \mathrm{Zr}$ particle in the Al matrix is always around or larger than $20 \mathrm{~nm}$, as shown in Figure 2a, just as the other work reported in References [1-5]. Therefore, to focus on the property of the interface and simplify the calculated unit cell, the interfaces between $\mathrm{Al}_{3} \mathrm{Zr}$ and the $\mathrm{Al}$ matrix are treated as flat and periodic during first-principle calculations. What is more, because of the best match of the $\mathrm{Al}_{3} \mathrm{Zr}(001)$ crystallographic plane with the $\mathrm{Al}$ (001) crystal face according to the lattice parameters shown in Table 1, the interface models were built as $\mathrm{Al}_{3} \mathrm{Zr}(001) / \mathrm{Al}(001)$ interfaces perpendicular to [001] crystal orientation.

(a)

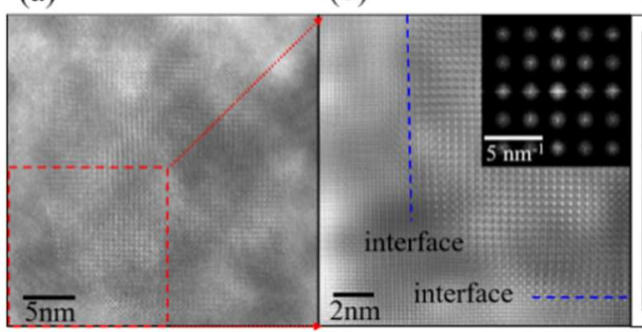

(c)

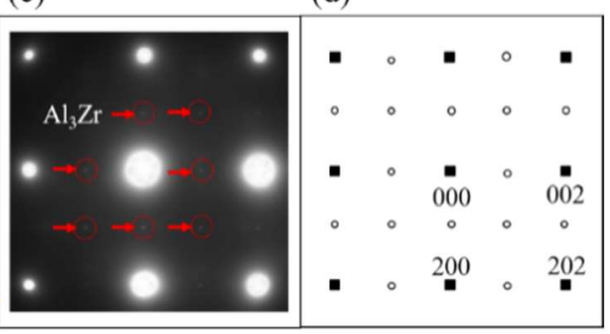

Figure 2. HRTEM and SAED images of $\mathrm{Al}_{3} \mathrm{Zr}$ in $\mathrm{Al}$ matrix ([100] zone axis). (a) HRTEM image of $\mathrm{Al}_{3} \mathrm{Zr}$ in $\mathrm{Al}$ matrix; (b) enlarged micrograph of $\mathrm{Al}_{3} \mathrm{Zr}$ in red frame of (a), with its fast Fourier transformation (FFT) as inset, where blue dashes present the major interfaces between particle and matrix; (c) SAED pattern of (a); (d) schematic representation of SAED pattern with projection along [100] zone axis, where small solid squares stand for $\mathrm{Al}$ matrix, and small open circles represent $\mathrm{Al}_{3} \mathrm{Zr}$.

To determine the most preferable interface mode, the initial calculated models were built with different terminals and different jointing (stacking) modes, namely the interfaces docking with different surface atoms and relative positions. In this work, the interface modes are built in two different forms. One is signed as the I-ter mode with indirect $\mathrm{Al} / \mathrm{Al}_{3} \mathrm{TM}$ jointing (Figure $3 \mathrm{~g}$ ), in which mode the $\mathrm{Al}$ matrix is jointed with the $\mathrm{Al}$ atoms layer in $\mathrm{Al}_{3} \mathrm{Zr}$ but not directly with the layer including the $\mathrm{Zr}$ atom. The other is the $\mathrm{D}$-ter mode with direct $\mathrm{Al} / \mathrm{Al}_{3} \mathrm{TM}$ binding (Figure 3h), in which mode the $\mathrm{Al}$ matrix is combined with the layer including the $\mathrm{Zr}$ atom in $\mathrm{Al}_{3} \mathrm{Zr}$ directly. In the I-ter mode, the interfacial properties of the adjacent $\mathrm{Al} / \mathrm{Al}$ interface are discussed by comparing them with $\mathrm{D}$-ter, which aims to distinguish its internal cohesion between the $\mathrm{Al}$ layer and $\mathrm{Al}_{3} \mathrm{TM}$ with the interfacial bonding energy in the D-ter mode. Three stacking modes including top-site stacking, bridge-site stacking, and central-site stacking are considered. The top views and side views of them are shown in Figure 3a-f, respectively. Convergence tests show that the further increase of the layers has no impact on the calculation results of interfacial properties on the condition that the thickness of the two substances in the interface is larger than five layers. Taking into account the different doping sites in Figure $3 \mathrm{~g}$, $\mathrm{h}$, the influence of Sc-doping on the interfacial properties is investigated. As shown in Figure 3, the sites of $\mathrm{Zr}$ atoms in crystal (Figure 1c) are equivalent, but they are nonequivalent in interfacial models (Figure 3g,h).

Crystal and interface models of Sc-doped $\mathrm{Al}_{3}(\mathrm{Zr}, \mathrm{Sc})$ are separately named $\mathrm{Al}_{3} \mathrm{Zr}(\mathrm{Sc} n-\mathrm{m})$ and $\mathrm{Al} / \mathrm{Al}_{3} \mathrm{Zr}$ (Sc n-m), respectively. The letter " $\mathrm{n}$ " represents the number of doped Sc elements in the calculation unit shown in Figures 1 and 3. The letter " $\mathrm{m}$ " is set on behalf of the doping sites of Sc. 
Models of $\mathrm{Al}_{3} \mathrm{Zr}(\mathrm{Sc} 2-1), \mathrm{Al}_{3} \mathrm{Zr}(\mathrm{Sc} 2-2)$, and $\mathrm{Al}_{3} \mathrm{Zr}(\mathrm{Sc} 2-3)$ are shown in Figure $2 \mathrm{c}-\mathrm{e}$, corresponding to an Sc-doping ratio of $1 / 2$ with different Sc-doping sites at A \& B, A \& C, and B \& $\mathrm{C}$, respectively. The structures with other doping ratios in the calculation unit cell all only have one structure each. However, interface models can be distinguished. $\mathrm{Al} / \mathrm{Al}_{3} \mathrm{Zr}(\mathrm{Sc} 1-1), \mathrm{Al} / \mathrm{Al}_{3} \mathrm{Zr}(\mathrm{Sc} 1-2)$, and $\mathrm{Al}_{1} \mathrm{Al}_{3} \mathrm{Zr}(\mathrm{Sc} 1-3)$ are all on behalf of the models with a $1 / 4 \mathrm{Sc}$-doping ratio, but correspond to different doped sites at $\mathrm{A}, \mathrm{B}$, and $\mathrm{C}$, respectively. $\mathrm{Al} / \mathrm{Al}_{3} \mathrm{Zr}(\mathrm{Sc} 2-1), \mathrm{Al} / \mathrm{Al}_{3} \mathrm{Zr}(\mathrm{Sc} 2-2)$, and $\mathrm{Al} / \mathrm{Al}_{3} \mathrm{Zr}(\mathrm{Sc} 2-3)$ are interface models with a $1 / 2 \mathrm{Sc}$-doping ratio that correspond to crystal models shown in Figure 2c-e, respectively. $\mathrm{Al} / \mathrm{Al}_{3} \mathrm{Zr}$ (Sc 2-4) model is constructed with $\mathrm{Al}_{3} \mathrm{Zr}$ (Sc 2-1) (shown in Figure 2c) cut from the middle section of planes containing $\mathrm{A}$ and $\mathrm{B} . \mathrm{Al} / \mathrm{Al}_{3} \mathrm{Zr}(\mathrm{Sc} 3-1), \mathrm{Al} / \mathrm{Al}_{3} \mathrm{Zr}(\mathrm{Sc} 3-2), \mathrm{Al} / \mathrm{Al}_{3} \mathrm{Zr}(\mathrm{Sc} 3-3)$, and $\mathrm{Al} / \mathrm{Al}_{3} \mathrm{Zr}$ (Sc 3-4) are models with an Sc-doping ratio of $3 / 4$ and correspond to different un-doped sites at $D, C, B$, and $A$, respectively.

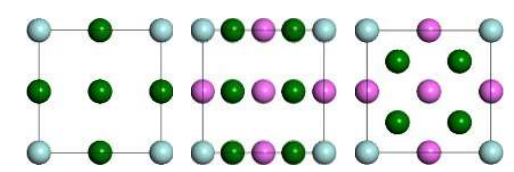

(a)

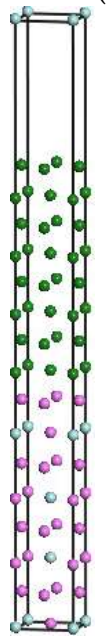

(d)

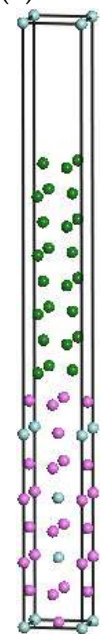

(e) (b)

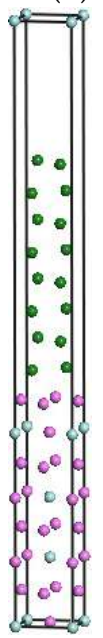

(f)

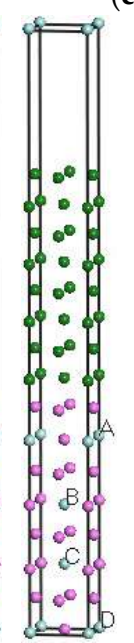

(g) (c)

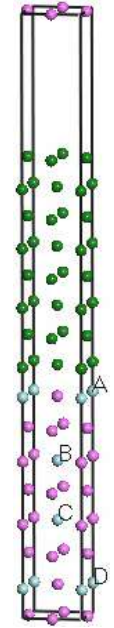

(h)

Figure 3. Interfacial stacking models paralleling to (001) plane. (a) top view of top-site model; (b) top view of bridge-site model; (c) top view of central-site model; (d) stereogram of top-site model; (e) stereogram of bridge-site model; (f) stereogram of central-site model; (g) $\mathrm{Al} / \mathrm{Al}_{3} \mathrm{TM}(\mathrm{I}$-ter); (h) $\mathrm{Al} / \mathrm{Al}_{3} \mathrm{TM}(\mathrm{D}$-ter $)$.

\subsection{Energy Calculation Method}

All energy calculations are performed by using the pseudo-potential plane-wave method [22] and are implemented through the Cambridge Serial Total Energy Package Program [23]. The electronic exchange-correlation energy is determined by using the generalized gradient approximation of Perdew-Burke-Ernzerh (GGA-PBE) [24]. All crystal structures are fully relaxed with respect to the volume, as well as to all cell-internal atomic coordinates. The convergence of results with respect to energy cutoff and $k$-points [25] is carefully considered. A plane-wave basis set is used with an energy cutoff of $330 \mathrm{eV}$. The summation over the Brillouin zone for the bulk structures is performed on a Monkhorst-pack $k$-point mesh with spacing of $0.04 \mathrm{~nm}^{-1}$ for all calculations. All atomic positions are optimized by using the Broyden-Flecher-Goldfarb-Shanno (BFGS) scheme [26] based on the cell optimization criterion. The convergence is confirmed with the system total energy fluctuation within $5 \times 10^{-6} \mathrm{eV}$, with the force on each atom in the unit cell less than $0.01 \mathrm{eV} / \AA$, with the residual stress of the unit cell lower than $0.02 \mathrm{GPa}$, and with the tolerance offset lower than $5 \times 10^{-6} \AA$. 
A series of first-principles calculations (at $0 \mathrm{~K}$ ) of the $\mathrm{Al}_{3} \mathrm{TM}\left(\mathrm{TM}=\mathrm{Ti}, \mathrm{Zr}, \mathrm{Hf}, \mathrm{Sc}\right.$ ) and $\mathrm{Al}_{3}\left(\mathrm{Zr}_{\text {, }}\right.$ Sc) phases, bulk Al, Ti, Zr, Hf, and Sc, and free atom Al, Ti, Zr, Hf, and Sc are calculated to explain the different formations of the intermetallic compounds. The formation enthalpies per atom $(\Delta H)$ of the $\mathrm{Al}_{3} \mathrm{TM}(\mathrm{TM}=\mathrm{Ti}, \mathrm{Zr}, \mathrm{Hf}, \mathrm{Sc})$ and $\mathrm{Al}_{3}(\mathrm{Zr}, \mathrm{Sc})$ phases can be calculated by using the following Equation (1) $[27,28]$ :

$$
\Delta H_{A_{n_{1}} B_{n_{2}}}=\frac{1}{n_{1}+n_{2}}\left[E_{t}^{A_{n_{1}} B_{n_{2}}}-n_{1} E_{s}^{A}-n_{2} E_{s}^{B}\right]
$$

where $E_{t}$ is the total energy calculated at $T=0 \mathrm{~K}$ and $E_{s}{ }^{A}$ and $E_{s}{ }^{B}$ are the energies per atom of bulk $A$ and $B$, respectively. All atoms are relaxed to their equilibrium geometries. The same potential function has been used in the total energy calculation of the intermetallics and bulk pure metals. The calculated energies per atom of bulk Al, Ti, Zr, Hf, and Sc are $-56.42 \mathrm{eV},-1603.07 \mathrm{eV},-1280.95 \mathrm{eV}$, $-408.84 \mathrm{eV}$, and $-1277.17 \mathrm{eV}$, respectively. Therefore, the formation enthalpies per atom of the intermetallics can be calculated.

The binding energies per atom $\left(E_{b}\right)$ of the $\mathrm{Al}_{3} \mathrm{TM}(\mathrm{TM}=\mathrm{Ti}, \mathrm{Zr}, \mathrm{Hf}, \mathrm{Sc})$ and $\mathrm{Al}_{3}(\mathrm{Zr}, \mathrm{Sc})$ phases can be calculated by using Equation (2) [29]:

$$
E_{b}^{A_{n_{1}} B_{n_{2}}}=-\frac{1}{n_{1}+n_{2}}\left[E_{t}^{A_{n_{1}} B_{n_{2}}}-n_{1} E_{a}^{A}-n_{2} E_{a}^{B}\right]
$$

where $E_{a}{ }^{A}$ and $E_{a}{ }^{B}$ are the energies per atom of free atoms $A$ and $B$, respectively. The calculated energies per atom of the free atoms $\mathrm{Al}, \mathrm{Ti}, \mathrm{Zr}, \mathrm{Hf}$, and $\mathrm{Sc}$ are $-52.66 \mathrm{eV},-1596.38 \mathrm{eV},-1273.70 \mathrm{eV}$, $-401.49 \mathrm{eV}$, and $-1272.62 \mathrm{eV}$, respectively, and the calculated binding energies are shown in Table 2.

\subsection{Elastic Properties Calculation Method}

By using the Voigt-Reuss-Hill approximation [30], we calculate the polycrystalline elastic properties, bulk modulus, and the shear modulus (shown in Table 3) on the basis of the second-order elastic constants, which are determined by means of linear fitting of the stress-strain curves [30].

$$
B=\left(B_{R}+B_{V}\right) / 2, G=\left(G_{R}+G_{V}\right) / 2
$$

The tetragonal system has six independent elastic constants: $C_{11}, C_{12}, C_{13}, C_{33}, C_{44}$, and $C_{66}$. The Voigt bounds $\left(B_{v}, G_{v}\right)$ and the Reuss bounds $\left(B_{R}, G_{R}\right)$ [31] are expressed below.

$$
\begin{gathered}
B_{V}=\left(2 C_{11}+2 C_{12}+C_{33}+4 C_{13}\right) / 9 \\
G_{V}=\left(2 C_{11}-C_{12}+C_{33}-2 C_{13}+6 C_{44}+3 C_{66}\right) / 15 \\
B_{R}=\left[\left(C_{11}+C_{12}\right) C_{33}-2 C_{13}^{2}\right] /\left(C_{11}+C_{12}+2 C_{33}-4 C_{13}\right) \\
G_{R}=\frac{15 C^{2}\left(C_{11}-C_{12}\right) C_{44} C_{66}}{2\left(C_{11}-C_{12}\right)\left(2\left(C_{11}+C_{12}\right)+4 C_{13}+C_{33}\right) C_{44} C_{66}+3 C^{2}\left(2 C_{44} C_{66}+\left(C_{11}-C_{12}\right)\left(C_{44}+2 C_{66}\right)\right.}
\end{gathered}
$$

where:

$$
C^{2}=C_{33}\left(C_{11}+C_{12}\right)-2 C_{13}^{2}
$$

The Young's modulus and Poisson's ratio [32] can be calculated by using the equation below.

$$
\begin{aligned}
& E=9 B G /(3 B+G) \\
& v=(3 B-E) /(6 B)
\end{aligned}
$$




\subsection{Griffith Rupture Work and Interfacial Energy Calculation Method}

The Griffith rupture work $(W)[33]$ is defined as the energy required per unit area to reversibly separate a bulk material into two semi-infinite bulks with two free surfaces. It is sometimes called the "ideal work of separation." In the present study, W is calculated according to Equation (11).

$$
W=-\left[E_{\mathrm{Al}_{3} \mathrm{TM} / \mathrm{Al}}-E_{\mathrm{Al}_{3} \mathrm{TM}}-E_{\mathrm{Al}}\right] / A
$$

where $E_{\mathrm{Al} 3 \mathrm{TM}}$ and $E_{\mathrm{Al}}$ are the total energies of the $\mathrm{Al}_{3} \mathrm{TM}(\mathrm{TM}=\mathrm{Ti}, \mathrm{Zr}, \mathrm{Hf}, \mathrm{Sc})$ and $\alpha$-Al with free surfaces, respectively. $E_{\mathrm{Al} 3 \mathrm{TM} / \mathrm{Al}}$ is the total energy of the $\mathrm{Al}_{3} \mathrm{TM} / \mathrm{Al}$ supercell embedded in Vacuum and $A$ is the area of the interface. All systems are calculated under exactly the same conditions ( $k$ mesh, cutoff energy, etc.). They are all subjected to the same lateral lattice strain set by the underlying lattice. Perpendicularly to the interface, all the atoms are fully relaxed. The Griffith rupture work calculated in this manner gives direct information regarding the strength and bonding of the interface and is taken as a measure for the mechanical stability and chemical bonding strength at the interface [33].

The interfacial energy $\gamma$ is calculated by using the equation below.

$$
\gamma=\left(E_{A l_{3} T M / A l}-\sigma_{A l_{3} T M} A-\sigma_{A l} A-E_{A l_{3} T M}^{B u l k}-E_{A l}^{B u l k}\right) / A,
$$

where $E_{A l 3 T M}{ }^{\text {Bulk }}, E_{A l}{ }^{\text {Bulk }}$ corresponds to the total energies of $\mathrm{Al}_{3} \mathrm{TM}(\mathrm{TM}=\mathrm{Ti}, \mathrm{Zr}, \mathrm{Hf}, \mathrm{Sc})$ and $\mathrm{Al}$ in bulk states and $\sigma_{\mathrm{Al}} \mathrm{TM}$ and $\sigma_{\mathrm{Al}}$ are the surface energies of the free surfaces of the $\mathrm{Al}_{3} \mathrm{TM}$ and $\mathrm{Al}$ matrix, respectively. All systems are subjected to the same lateral strain imposed by the underlying lattice. The surface energies are calculated relative to the bulk suffering the same strain as the interface.

$$
\sigma_{X}=\left(E_{X}-E_{X}^{B u l k}\right) / 2 A,
$$

where $\mathrm{X}$ stands for $\mathrm{Al}_{3} \mathrm{TM}$ or the $\mathrm{Al}$ matrix. Combining Equations (2)-(4), the interfacial energy can also be expressed as the following equation:

$$
\gamma=\sigma_{\eta^{\prime}}+\sigma_{A^{l}}-W
$$

Equation (5) presents the relationship between $W$ and $\gamma$ and shows that the interfacial energy varies in a contradictory way to the work of separation.

\section{Results and Discussion}

\subsection{Energy}

Table 2 shows the calculated formation enthalpies and binding energies per atom of the four intermetallics of $\mathrm{Al}_{3} \mathrm{TM}(\mathrm{TM}=\mathrm{Ti}, \mathrm{Zr}, \mathrm{Hf}, \mathrm{Sc})$. The results show that the absolute value of formation enthalpy for the intermetallics decreases in the following order: $\mathrm{Al}_{3} \mathrm{Zr}>\mathrm{Al}_{3} \mathrm{Sc}>\mathrm{Al}_{3} \mathrm{Hf}>\mathrm{Al}_{3} \mathrm{Ti}$. All the absolute values are higher than the main strengthening phases $\left(\mathrm{MgZn}_{2}, \mathrm{Al}_{2} \mathrm{CuMg}, \mathrm{Al}_{2} \mathrm{Cu}\right)$ in $\mathrm{Al}-\mathrm{Zn}-\mathrm{Mg}-\mathrm{Cu}$ alloys [28]. Formation enthalpy is defined as the released or absorbed energy during the reaction, which shows the ease or difficulty for the formation of intermetallics. On the condition that formation enthalpy is negative, a larger absolute value means easier formation of the intermetallic phase. According to this theory, these four intermetallics of $\mathrm{Al}_{3} \mathrm{TM}(\mathrm{TM}=\mathrm{Ti}, \mathrm{Zr}, \mathrm{Hf}, \mathrm{Sc})$ can all act as grain refiners for $\mathrm{Al}$ alloys. Furthermore, among these four compounds, the formation of $\mathrm{Al}_{3} \mathrm{Zr}$ is easiest during the solidification process under the same circumstance, which is beneficial to its nucleation and contributes to the Al-matrix's grain refining. Based on the phases' energy analysis, $\mathrm{Al}_{3} \mathrm{Zr}$ is the most suitable for use as a grain refiner among these four intermetallics. 
Table 2. Enthalpy of the $\mathrm{Al}_{3} \mathrm{TM}(\mathrm{TM}=\mathrm{Ti}, \mathrm{Zr}, \mathrm{Hf}, \mathrm{Sc})$ phases in the primitive units and the formation enthalpy and binding energy of the calculated intermetallics.

\begin{tabular}{|c|c|c|c|c|c|c|c|c|c|c|c|c|}
\hline Phases & $\mathrm{Al}_{3} \mathrm{Ti}$ & & & $\mathrm{Al}_{3} \mathrm{Zr}$ & & & $\mathrm{Al}_{3} \mathrm{Hf}$ & & & $\mathrm{Al}_{3} \mathrm{Sc}$ & & \\
\hline & $\begin{array}{l}\text { Cal. [This } \\
\text { Work] }\end{array}$ & Cal. & Exp. & $\begin{array}{l}\text { Cal. [This } \\
\text { Work] }\end{array}$ & Cal. & Exp. & $\begin{array}{l}\text { Cal. [This } \\
\text { Work] }\end{array}$ & Cal. & Exp. & $\begin{array}{l}\text { Cal. [This } \\
\text { Work] }\end{array}$ & Cal. & Exp. \\
\hline$\Delta \mathbf{H}(\mathrm{eV} /$ atom $)$ & -0.44 & & & -0.53 & & & -0.44 & & & -0.45 & $-0.45[9]$ & $-0.45[34]$ \\
\hline$\Delta \mathbf{H}(\mathrm{kJ} / \mathrm{mol})$ & -42.39 & $\begin{array}{l}-38.90[16] \\
-41.45[35] \\
-41.90[36] \\
-39.51[37]\end{array}$ & $-39.2[38]$ & -50.65 & $\begin{array}{l}-49.11[16] \\
-51.06[13] \\
-53.45[39]\end{array}$ & $\begin{array}{c}-49 \pm 4[40] \\
-48.4 \pm 1.3[41]\end{array}$ & -42.85 & $\begin{array}{l}-39.63[16] \\
-40.00[20]\end{array}$ & $\begin{array}{l}-40.6 \pm 0.8[42] \\
-44.7 \pm 2.4[43]\end{array}$ & -43.41 & & \\
\hline $\mathrm{E}_{\mathrm{b}}(\mathrm{eV} /$ atom $)$ & 4.524 & & & 5.157 & & & 4.107 & & & 4.048 & & \\
\hline $\mathrm{E}_{\mathbf{b}}(\mathrm{kJ} / \mathrm{mol})$ & 436.27 & & & 495.85 & & & 396.07 & & & 423.80 & & \\
\hline
\end{tabular}


The binding energy of the intermetallics decreases in the following order: $\mathrm{Al}_{3} \mathrm{Zr}>\mathrm{Al}_{3} \mathrm{Ti}>\mathrm{Al}_{3} \mathrm{Sc}>\mathrm{Al}_{3} \mathrm{Hf}$. The binding energy represents the strength of atomic bonding and reflects the stability of the phase. Again, $\mathrm{Al}_{3} \mathrm{Zr}$ has the largest binding energy among the four intermetallic phases, which means that the atomic bonding of $\mathrm{Al}_{3} \mathrm{Zr}$ is strongest and most difficult to dissolve. Following heat treatment after being casted, $\mathrm{Al}_{3} \mathrm{Zr}$ is a perfect particle to pin the dislocation and grain boundary that is contributing to hindering grain growth and grain refinement. On the contrary, $\mathrm{Al}_{3} \mathrm{Ti}$ has the lowest absolute value of formation enthalpy and a comparatively higher binding energy. It is the least suitable for acting as a grain refiner among the four intermetallics based on the energy analysis.

\subsection{Elastic Properties}

The calculated elastic results of the four phases are shown in Table 3. The Young's moduli of these intermetallics decrease in the following order: $\mathrm{Al}_{3} \mathrm{Zr}>\mathrm{Al}_{3} \mathrm{Ti}>\mathrm{Al}_{3} \mathrm{Hf}>\mathrm{Al}_{3} \mathrm{Sc}_{\mathrm{Al}_{3}} \mathrm{Zr}$ achieves the highest Young's modulus, which means that this phase can act as a strengthening phase in the $\mathrm{Al}$ matrix during deformation. However, according to Pugh's criterion [44], a material is brittle (ductile) if the $B / G$ value is less (greater) than 1.75. What is more, a low (high) Possion's ratio is the representation of brittleness (toughness) of materials [29]. Based on these two criterions, the ductility of the four intermetallics decreases in the following order: $\mathrm{Al}_{3} \mathrm{Hf}>\mathrm{Al}_{3} \mathrm{Sc}>\mathrm{Al}_{3} \mathrm{Ti}>\mathrm{Al}_{3} \mathrm{Zr}$. As a result, the brittleness of the $\mathrm{Al}_{3} \mathrm{Ti}$ or $\mathrm{Al}_{3} \mathrm{Zr}$ phase implies that their existence may act as a crack initiation point. However, the calculated results show that $\mathrm{Sc}$-doped $\mathrm{Al}_{3} \mathrm{Zr}$ can effectively promote its ductility as $\mathrm{Al}_{3}(\mathrm{Zr}, \mathrm{Sc})$ particles simultaneously with a high Young modulus. Furthermore, Poisson's ratio $v$ shows the condition of the atomic binding force. When $v$ lies between 0.25 and 0.5 , it means that the atomic binding force is a central force. The data in Table 4 show that the atomic binding force of $\mathrm{Al}_{3} \mathrm{TM}$ $\left(\mathrm{TM}=\mathrm{Ti}, \mathrm{Zr}, \mathrm{Hf}, \mathrm{Sc}\right.$ ) phases is not the central force. Based on the results of elastic properties, $\mathrm{Al}_{3} \mathrm{Hf}$ and $\mathrm{Al}_{3}(\mathrm{Zr}, \mathrm{Sc})$ are more suitable for use as grain refiners than $\mathrm{Al}_{3} \mathrm{Ti}$.

Table 3. Calculated bulk modulus $B(G P a)$, shear modulus $G(G P a)$, Young's modulus $E(G P a), B / G$, Poisson's ratio $v$, and Debye temperature $\Theta_{D}(K)$ of the $\mathrm{Al}_{3} \mathrm{TM}(\mathrm{TM}=\mathrm{Ti}, \mathrm{Zr}, \mathrm{Hf}, \mathrm{Sc})$ phases.

\begin{tabular}{|c|c|c|c|c|c|c|c|c|c|}
\hline \multirow{2}{*}{ Phases } & \multicolumn{2}{|c|}{$\mathrm{Al}_{3} \mathrm{Ti}$} & \multicolumn{2}{|c|}{$\mathrm{Al}_{3} \mathrm{Zr}$} & \multicolumn{2}{|c|}{$\mathrm{Al}_{3} \mathrm{Hf}$} & \multicolumn{2}{|c|}{$\mathrm{Al}_{3} \mathrm{Sc}$} & \multirow{2}{*}{$\begin{array}{c}\mathrm{Al}_{12} \mathrm{Zr}_{3} \mathrm{Sc} \\
\text { This } \\
\text { Work }\end{array}$} \\
\hline & $\begin{array}{l}\text { This } \\
\text { Work }\end{array}$ & Other Work & $\begin{array}{l}\text { This } \\
\text { Work }\end{array}$ & Other Work & $\begin{array}{l}\text { This } \\
\text { Work }\end{array}$ & Other Work & $\begin{array}{l}\text { This } \\
\text { Work }\end{array}$ & $\begin{array}{l}\text { Other } \\
\text { Work }\end{array}$ & \\
\hline $\mathrm{B}_{\mathrm{V}}$ & 102.4 & & 100.8 & & 106.5 & & 92.1 & & 96.7 \\
\hline$B_{R}$ & 102.2 & & 100.6 & & 106.0 & & 91.8 & & 96.5 \\
\hline B & 102.3 & $\begin{array}{c}102[45] \\
103[5] \\
107[46]\end{array}$ & 100.7 & $\begin{array}{l}105.3[46] \\
102.2[47]\end{array}$ & 106.3 & 108.2 [46] & 91.9 & 91.8 [48] & 96.6 \\
\hline $\mathrm{G}_{\mathrm{V}}$ & 81.8 & & 84.6 & & 77.8 & & 74.1 & & 79.2 \\
\hline $\mathrm{G}_{\mathrm{R}}$ & 81.7 & & 83.3 & & 77.4 & & 71.7 & & 77.0 \\
\hline G & 81.8 & 88.5 [46] & 84.0 & $\begin{array}{l}83.2[46] \\
85.1[47]\end{array}$ & 77.6 & 80.3 [46] & 72.9 & $71.7[48]$ & 78.1 \\
\hline E & 193.8 & 208.5 [46] & 197.2 & $\begin{array}{l}197.6 \text { [46] } \\
201.8 \text { [47] }\end{array}$ & 187.2 & $193.3[46]$ & 173.1 & & 184.6 \\
\hline $\mathrm{B} / \mathrm{G}$ & 1.25 & $1.22[48][46]$ & 1.20 & $1.26[46,47]$ & 1.37 & 1.35 [46] & 1.26 & & 1.24 \\
\hline$v$ & 0.18 & & 0.17 & & 0.21 & & 0.19 & & 0.18 \\
\hline
\end{tabular}

Micro-cracks are easy to induce in materials because of significant elastic anisotropy [49]. Therefore, elastic anisotropy should be calculated to predict the mechanical durability of materials. A 3D curved surface, which represents the dependence of elastic properties on crystallographic directions, can indicate the elastic anisotropy of crystal structures. The Young's moduli with directional dependence for tetragonal crystal are defined in Equation (15) [50].

$$
E_{\mathrm{T}}=1 /\left[\left(l_{1}^{4}+l_{2}^{4}\right) S_{11}+l_{3}^{4} S_{33}+l_{1}^{2} l_{2}^{2}\left(2 S_{12}+S_{66}\right)+l_{3}^{2}\left(1-l_{3}^{2}\right)\left(2 S_{13}+S_{44}\right)+2 l_{1} l_{2}\left(l_{1}^{2}-l_{2}^{2}\right) S_{16}\right]
$$

where $S_{i j}$ is the elastic compliance constant and $l_{1}, l_{2}$, and $l_{3}$ are the directional cosines to the $X, Y$, and $Z$ axes, respectively. Figure 4 shows the bulk moduli and Young's moduli with directional dependence 
of $\mathrm{Al}_{3} \mathrm{TM}(\mathrm{TM}=\mathrm{Ti}, \mathrm{Zr}, \mathrm{Hf}, \mathrm{Sc})$ and $\mathrm{Al}_{12} \mathrm{Zr}_{3} \mathrm{Sc}$ combined with the projection of the calculated elastic moduli on the $X Y, X Z$, and $Y Z$ planes.
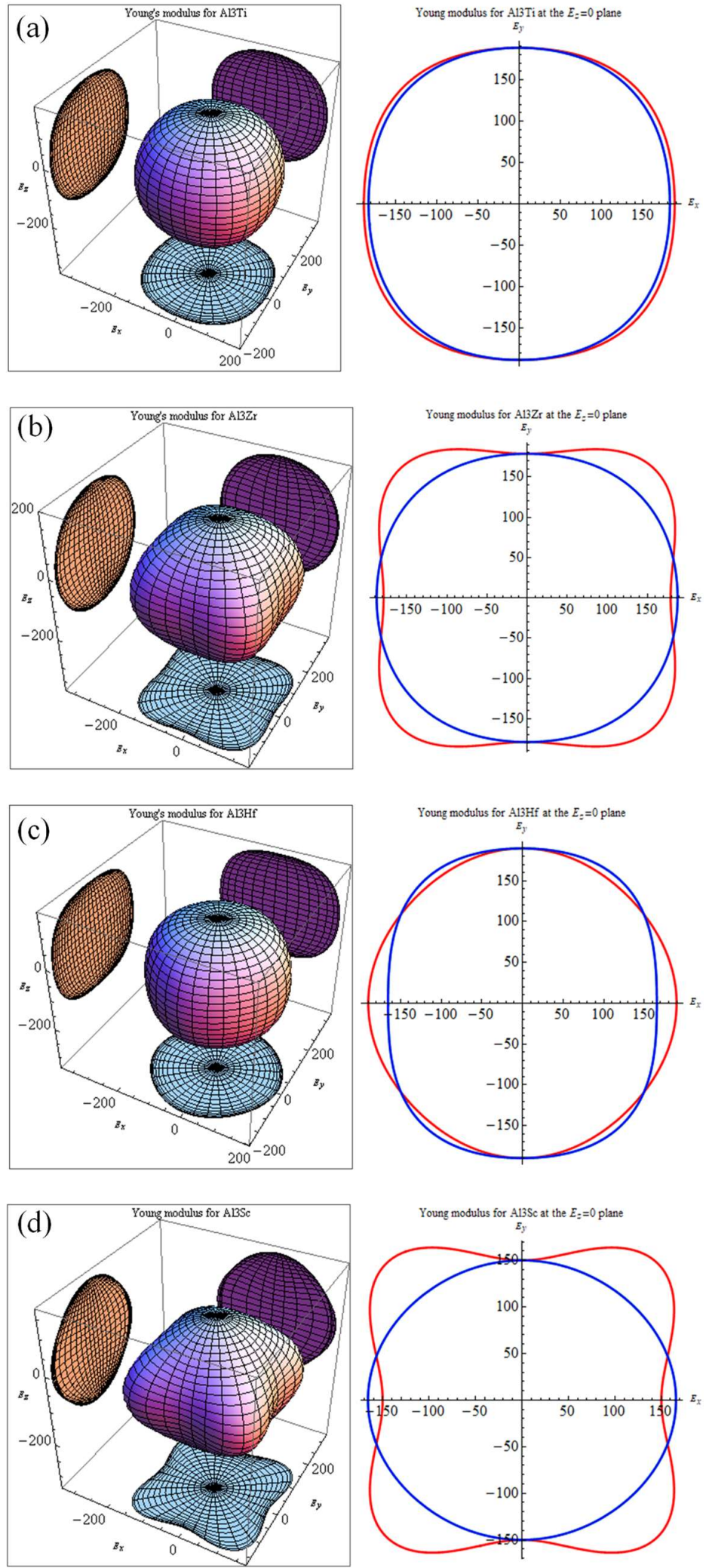

Figure 4. Cont. 

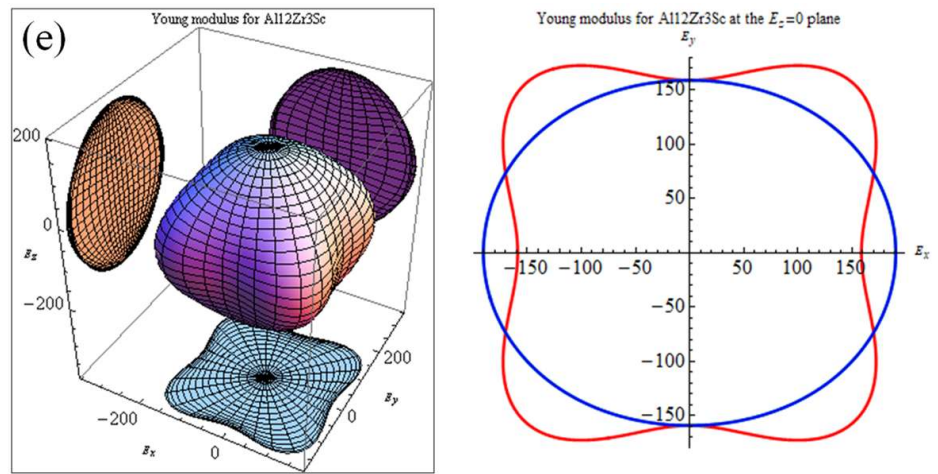

Figure 4. Directional dependences of Young's moduli for (a) $\mathrm{Al}_{3} \mathrm{Ti}$, (b) $\mathrm{Al}_{3} \mathrm{Zr}$, (c) $\mathrm{Al}_{3} \mathrm{Hf}$, (d) $\mathrm{Al}_{3} \mathrm{Sc}$, and (e) $\mathrm{Al}_{12} \mathrm{Zr}_{3} \mathrm{Sc}$; projections of the directional dependent Young's moduli in different planes for $\mathrm{Al}_{3} \mathrm{Ti}$, $\mathrm{Al}_{3} \mathrm{Zr}, \mathrm{Al}_{3} \mathrm{Hf}, \mathrm{Al}_{3} \mathrm{Sc}$, and $\mathrm{Al}_{12} \mathrm{Zr}_{3} \mathrm{Sc}$. The units are in GPa.

Theoretically, the curved surface in an isotropic system should be spherical, whereas the deviation from the spherical shape indicates the extent of elastic anisotropy. It is true that the anisotropy of the disoriented precipitation should not be reflected in the macro performance. However, the anisotropy of the intermetallics may determine local strain imposed by external stress and may result in the generation of micro-cracks. Thus, the anisotropy and relative orientation distribution may affect alloy performances. Comparatively, $\mathrm{Al}_{3} \mathrm{Sc}$ shows a more serious anisotropy than $\mathrm{Al}_{3} \mathrm{Zr}$. As a result, if $\mathrm{Sc}$ is added as a grain finer together with the $\mathrm{Zr}$ element, the Young's modulus of Sc-doped $\mathrm{Al}_{12} \mathrm{Zr}_{3} \mathrm{Sc}_{1}$ with the Sc-doping ratio at $1 / 4$ can show a more favorable isotropy property, which is shown in Figure 4e. This means it may be a better grain refiner than $\mathrm{Al}_{3} \mathrm{Sc}$ [3]. From the elasticity perspective, the simultaneous addition of $\mathrm{Zr}$ and $\mathrm{Sc}$ is better than adding Sc individually.

Table 4. Griffith rupture work $\left(W_{\mathrm{ad}}\right)$, surface energy $\left(\sigma_{\text {suf }}\right)$, and interfacial energy $\left(\gamma_{\text {int }}\right)$ of $\mathrm{Al}_{3} \mathrm{TM}(001) / \mathrm{Al}(001)$ interfaces $\left(\sigma_{\text {suf }(\mathrm{Al})}=1.038\left(\mathrm{~J} / \mathrm{m}^{2}\right)\right)$.

\begin{tabular}{|c|c|c|c|c|c|c|c|c|c|}
\hline \multicolumn{2}{|c|}{ Interfaces Stacking Site } & \multicolumn{2}{|c|}{$\mathrm{Al}_{3} \mathrm{Ti}(001) / \mathrm{Al}(001)$} & \multicolumn{2}{|c|}{$\mathrm{Al}_{3} \mathrm{Zr}(001) / \mathrm{Al}(001)$} & \multicolumn{2}{|c|}{$\mathrm{Al}_{3} \mathrm{Hf}(001) / \mathrm{Al}(001)$} & \multicolumn{2}{|c|}{$\mathrm{Al}_{3} \mathrm{Sc}(001) / \mathrm{Al}(001)$} \\
\hline Type & & D-ter & I-ter & D-ter & I-ter & D-ter & I-ter & D-ter & I-ter \\
\hline \multirow[t]{3}{*}{$W_{\mathrm{ad}}\left(\mathrm{J} / \mathrm{m}^{2}\right)$} & Top & 2.610 & 2.877 & 2.783 & 2.894 & 2.752 & 2.886 & 2.491 & 2.985 \\
\hline & Bridge & - & - & - & - & - & - & - & - \\
\hline & Central & - & 2.450 & - & 2.772 & - & 2.758 & - & 2.740 \\
\hline$\sigma_{\text {suf }}\left(\mathrm{J} / \mathrm{m}^{2}\right)$ & $\mathrm{Al}_{3} \mathrm{TM}$ & 2.030 & 1.923 & 1.824 & 1.751 & 1.835 & 1.780 & 1.445 & 1.444 \\
\hline \multirow[t]{3}{*}{$\gamma_{\text {int }}\left(J / m^{2}\right)$} & Top & 0.458 & 0.084 & 0.079 & -0.105 & 0.121 & -0.068 & -0.008 & -0.503 \\
\hline & Bridge & - & - & - & - & - & - & - & - \\
\hline & Central & - & 0.511 & - & 0.017 & - & 0.06 & - & -0.258 \\
\hline
\end{tabular}

"-" indicates instability. Atoms in bridge-site stacking modes all shift to top or central sites after geometry optimization. Central-site stacking modes with D-ter types are also partially unstable, which shows that atoms move to top sites after geometry optimization.

\subsection{Griffith Rupture Work and Interfacial Energy of $\mathrm{Al}(001) / A l_{3} T M(001)$}

Table 4 tabulates the Griffith rupture work $\left(W_{\text {ad }}\right)$, surface energy $\left(\sigma_{\text {suf }}\right)$, and interfacial energy $\left(\gamma_{\text {int }}\right)$ of two kinds of interface models with I-ter and D-ter (shown in Figure 3). It was found that only the top-site stacking modes and part of the central-site stacking modes are stable. Additionally, the top-site modes are more stable than the central-site stacking modes. Furthermore, the Griffith rupture work $\left(W_{\mathrm{ad}}\right)$ of I-ter models is generally higher than that of D-ter models, which means that the combination mode of $\mathrm{Al}_{3} \mathrm{TM}\left(\mathrm{TM}=\mathrm{Ti}, \mathrm{Zr}, \mathrm{Hf}, \mathrm{Sc}\right.$ ) with the $\mathrm{Al}$ matrix tends to occur more often with I-ter in $\mathrm{Al}_{3} \mathrm{TM}$ intermetallics. Besides, the lower surface energy of the $\mathrm{Al}_{3} \mathrm{TM}$ models with I-ter compared with D-ter (shown in Table 4) also shows that $\mathrm{Al}_{3} \mathrm{TM}$ is more likely to be exposed to an external environment with I-ter based on the lowest energy criterion. The Griffith rupture work of the $\mathrm{Al} / \mathrm{Al}_{3} \mathrm{TM}$ interface in I-ter is much larger than that in D-ter modes. In other words, even the bonding strength of the 
neighboring $\mathrm{Al} / \mathrm{Al}$ interface is higher than the direct $\mathrm{Al} / \mathrm{Al}_{3} \mathrm{TM}$ interface in D-ter modes, which remarkably characterizes the good wetting property or cohesion of the $\mathrm{Al}(001) / \mathrm{Al}_{3} \mathrm{TM}(001)$ interface with D-ter. This is consistent with [8]. The Griffith rupture work with I-ter decreases in the following order: $\mathrm{Al}_{3} \mathrm{Sc}>\mathrm{Al}_{3} \mathrm{Zr}>\mathrm{Al}_{3} \mathrm{Hf}>\mathrm{Al}_{3} \mathrm{Ti}$, which indicates that the binding strength of $\mathrm{Al}_{3} \mathrm{Sc}$ with the $\mathrm{Al}$ matrix is higher than the others. Additionally, $\mathrm{Al}_{3} \mathrm{Zr}$ also shows a good performance for combining with the $\mathrm{Al}$ matrix. From the interface perspective, it can also be deduced that $\mathrm{Al}_{3} \mathrm{Zr}$ doped with $\mathrm{Sc}$ can effectively improve its binding strength with the $\mathrm{Al}$ matrix.

Interface energy $\left(\gamma_{\mathrm{int}}\right)$ is defined as the excess energy per unit area during an interface forming. This is intrinsically caused by the changes of interfacial chemical bonds and structure strain between the two substances constructing the interface. Therefore, the stability of an interface can be assessed by its interface energy. Basically, if both of the materials are more distinct, then the $\gamma_{\text {int }}$ will be larger and the interface will be more unstable [51]. For the two different terminals, the interface energy of the models shows the same increasing sequence as $\mathrm{Al}_{3} \mathrm{Sc}<\mathrm{Al}_{3} \mathrm{Zr}<\mathrm{Al}_{3} \mathrm{Hf}<\mathrm{Al}_{3} \mathrm{Ti}$. First, this is due to the different lattice deviations of $\mathrm{Al}_{3} \mathrm{TM}$ from $\mathrm{Al}$, which are shown in the same order of $\mathrm{Al}_{3} \mathrm{Sc}<\mathrm{Al}_{3} \mathrm{Zr}<\mathrm{Al}_{3} \mathrm{Hf}<\mathrm{Al}_{3} \mathrm{Ti}$ (as shown in Table 1). Among these interfaces, $\mathrm{Al}_{3} \mathrm{Ti}$ has a positive interface energy, which is mainly caused by the structure mismatch and interfacial strain [51] shown in Table 1. This explains why $\mathrm{Al}_{3} \mathrm{Ti}$ cannot be a favorable grain refiner even though it shows a perfect performance in terms of its elastic properties, which was discussed in Section 3.2. In addition, due to the small absolute value of the interface energy of the $\mathrm{Al}_{3} \mathrm{Hf} / \mathrm{Al}$ interface, the driving force to form the $\mathrm{Al}_{3} \mathrm{Hf} / \mathrm{Al}$ interface is limited, so the formation of the $\mathrm{Al}_{3} \mathrm{Hf} / \mathrm{Al}$ interface is restricted during solidification, which imposes a detrimental effect on its refining ability. In contrast, the negative interface energies of $\mathrm{Al}_{3} \mathrm{Sc}$ and $\mathrm{Al}_{3} \mathrm{Zr}$ with the $\mathrm{Al}$ matrix are large enough to affirm their inter-diffusion of the interfacial joint [52]. It is believed that the interface with a negative $\gamma_{\text {int }}$ will provide a driving force to push interfacial atoms diffusing across the interface and bring them into the interfacial alloying, as well as potentially form an interfacial new phase. Therefore, the negative interface energy has significantly more influence on the interfacial structure and morphology. Among the eight interface models, the combination of I-ter $\mathrm{Al}_{3} \mathrm{Sc}$ with the $\mathrm{Al}$ matrix has the lowest negative interface energy, which confirms the positive wetting ability of Sc element in the interface. As such, Sc is a favorable additive element for $\mathrm{Al}_{3} \mathrm{Zr}$ to further improve its dispersion precipitation in the $\mathrm{Al}$ matrix during solidification, which is beneficial for further refining and strengthening the aluminum alloy.

\subsection{Sc-Doped $A l_{3}(\mathrm{Zr}, \mathrm{Sc})$ Phase and $A l / A l_{3}(\mathrm{Zr}, \mathrm{Sc})$ Interface}

\subsubsection{Energy of $\mathrm{Al}_{3}(\mathrm{Zr}, \mathrm{Sc})$}

The formation enthalpy and binding energy of the $\mathrm{Al}_{3}(\mathrm{Zr}, \mathrm{Sc})$ models defined in Section 2.1 are shown in Table 5. Along with these models, we have calculated the formation energies of $\mathrm{Al}_{3}(\mathrm{Zr}, \mathrm{Sc})$ series with an Sc: $Z r$ ratio from 1:16 to 15:16 by using $2 \times 2 \times 1$ supercell models as stated in Section 2.1 and found that the formation enthalpy of $\mathrm{Al}_{3}(\mathrm{Zr}, \mathrm{Sc})$ was the minimum value with $\mathrm{Sc}: \mathrm{Zr}$ at 1:3 It is shown that the absolute value of the formation enthalpy of $\mathrm{Al}_{3} \mathrm{Zr}(\mathrm{Sc1}-1)$ with the Sc: $\mathrm{Zr}$ ratio at 1:3 is higher than that of both $\mathrm{Al}_{3} \mathrm{Zr}$ and $\mathrm{Al}_{3} \mathrm{Sc}$, which means that $\mathrm{Al}_{3} \mathrm{Zr}(\mathrm{Sc} 1-1)$ has the highest nucleation driving force. Additionally, $\mathrm{Al}_{3} \mathrm{Zr}(\mathrm{Sc} 1-1)$ has a higher absolute value of binding energy than other $\mathrm{Al}_{3}(\mathrm{Zr}, \mathrm{Sc})$ models, which leads to a higher melting point and results in a higher precipitation temperature during solidification. This means the $\mathrm{Al}_{3} \mathrm{Zr}(\mathrm{Sc} 1-1)$ structure is the easiest model to nucleate under the condition of adding Sc and $\mathrm{Zr}$ simultaneously. It will be presented as a composite precipitate with staggered $\mathrm{Zr}$ and Sc atoms, which is consistent with the experimental phenomenon showing an Sc: $\mathrm{Zr}$ ratio at about 1:3 to 1:4 in $\mathrm{Al}_{3}(\mathrm{Zr}, \mathrm{Sc})$ particles in Reference [53]. In addition, based on the lowest interfacial energy of $\mathrm{Al} / \mathrm{Al}_{3} \mathrm{Sc}$, Sc atoms will get priority to take up the interfacial sites and construct the core-shell structure, which is shown in Figure 5a. When the ratio of Sc:Zr is lower than $1: 3$, redundant $\mathrm{Zr}$ atoms will nucleate as part of the $\mathrm{Al}_{3} \mathrm{Zr}$ phase with $\mathrm{Al}$ atoms. Since solidification is 
an unbalanced process, the nucleation of $\mathrm{Al}_{3} \mathrm{Zr}(\mathrm{Sc1}-1)$ and $\mathrm{Al}_{3} \mathrm{Zr}$ will form a competitive situation in the actual experiment.

Table 5. Formation enthalpy and binding energy of $\mathrm{Al}_{3}(\mathrm{Zr}, \mathrm{Sc})$.

\begin{tabular}{|c|c|c|c|c|}
\hline Phases & $\Delta H(\mathrm{eV} /$ atom $)$ & $\Delta H(\mathrm{~kJ} / \mathrm{mol})$ & $E_{\mathrm{b}}(\mathrm{eV} /$ atom $)$ & $E_{\mathrm{b}}(\mathrm{kJ} / \mathrm{mol})$ \\
\hline $\mathrm{Al}_{3} \mathrm{Zr}(\mathrm{Sc} 1-1)$ & -0.532 & -51.14 & -4.996 & -480.35 \\
\hline $\mathrm{Al}_{3} \mathrm{Zr}(\mathrm{Sc} 2-1)$ & -0.504 & -48.44 & -4.799 & -461.42 \\
\hline $\mathrm{Al}_{3} \mathrm{Zr}(\mathrm{Sc} 2-2)$ & -0.509 & -48.98 & -4.804 & -461.96 \\
\hline $\mathrm{Al}_{3} \mathrm{Zr}(\mathrm{Sc} 2-3)$ & -0.509 & -48.98 & -4.804 & -461.96 \\
\hline $\mathrm{Al}_{3} \mathrm{Zr}(\mathrm{Sc} 3-1)$ & -0.481 & -46.27 & -4.608 & -443.03 \\
\hline $\mathrm{Al}_{3} \mathrm{Sc}$ & -0.450 & -43.27 & -4.408 & -423.80 \\
\hline $\mathrm{Al}_{3} \mathrm{Zr}$ & -0.524 & -50.42 & -5.157 & -495.85 \\
\hline
\end{tabular}

Based on the high absolute value of $\mathrm{Al}_{3} \mathrm{Sc} / \mathrm{Al}$ interfacial energy (shown in Table 4) and the high absolute value of $\mathrm{Al}_{3} \mathrm{Zr}_{\mathrm{r}}$ 's formation enthalpy (shown in Table 2), the core-shell structure with $\mathrm{Al}_{3} \mathrm{Zr}$-core or $\mathrm{Al}_{3} \mathrm{Zr}(\mathrm{Sc1}-1)$-core sphered with an Sc-rich shell can be formed, as shown in Figure 5 . On the other hand, under the condition of an Sc:Zr ratio higher than 1:3, there will also be a competitive nucleation of $\mathrm{Al}_{3} \mathrm{Zr}(\mathrm{Sc1}-1)$ and other $\mathrm{Al}_{3} \mathrm{Zr}$ phases based on their high absolute value of formation enthalpy and binding energy and the excessive Sc atoms then form a shell cladding the core. As a result, the core-shell structures of $\mathrm{Al}_{3}(\mathrm{Zr}, \mathrm{Sc})$ are shown in experiments [54].

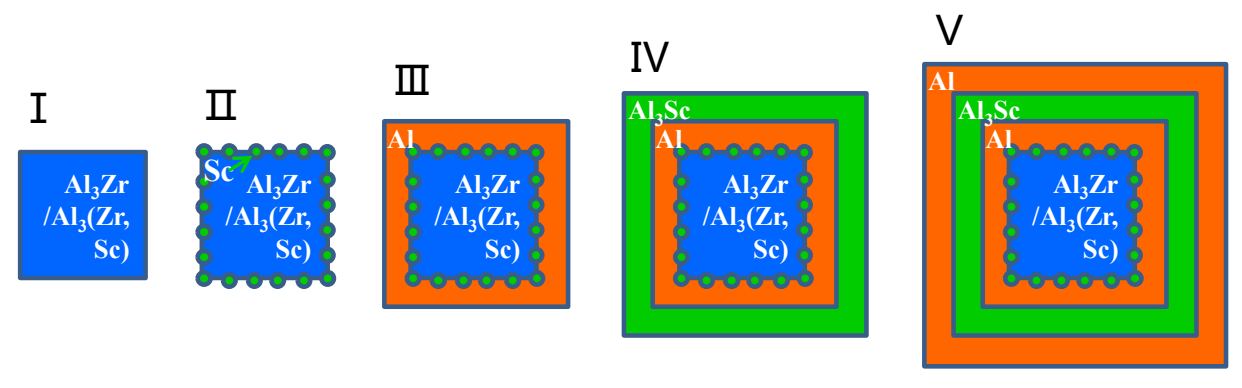

Figure 5. The schematic diagram of core-shell structure forming during solidification process with $\mathrm{Al}_{3}(\mathrm{Zr}, \mathrm{Sc})$ or as nuclei.

\subsubsection{Griffith Rupture Work and Interfacial Energy of $\mathrm{Al}(001) / \mathrm{Al}_{3}(\mathrm{Zr}, \mathrm{Sc})(001)$}

The Griffith rupture work of interfacial models with different doping sites and doping ratios (contrast with Figure 3) is shown in Table 6. From the data, it can be concluded once again that even with Sc doping, interface models with I-ter are more stable than D-ter, which shows that the Griffith rupture works of I-ter models are all higher than that of D-ter ones. Furthermore, the Griffith rupture work of $\mathrm{Al} / \mathrm{Al}_{3} \mathrm{Zr}$ (Sc1-1) (I-ter) (shown in Table 6) is higher than both $\mathrm{Al} / \mathrm{Al}_{3} \mathrm{Zr}(\mathrm{I}$-ter) and $\mathrm{Al} / \mathrm{Al}_{3} \mathrm{Sc}$ (I-ter) (shown in Table 4). This is due to the low interfacial energy of $\mathrm{Al} / \mathrm{Al}_{3} \mathrm{Sc}$ (shown in Table 4), the low surfacial energy of $\mathrm{Al}_{3} \mathrm{Sc}$ (shown in Table 4), and the high binding energy of $\mathrm{Al}_{3} \mathrm{Zr}$ (shown in Table 2). All these factors effectively lead to the beneficial effect of Sc doping on the improvement of the interface bond strength. As a result, the sites neighboring the interface are liable to be occupied by Sc atoms. However, the Griffith rupture work shows weak differences in the various doping sites in the interfacial modes, which just show the bonding strength of the interfaces. It can also be summarized that the ratio of Sc: $\mathrm{Zr}$ being higher than 1:3 does little good to the interface strengthening. Consequently, Sc-doped $\mathrm{Al}_{3}(\mathrm{Zr}, \mathrm{Sc})$ with the Sc: $\mathrm{Zr}$ ratio at 1:3 is beneficial to its nucleation as a grain refiner and as an improvement of interface strength by combining the property of $\mathrm{Al}_{3}(\mathrm{Zr}, \mathrm{Sc})$ (shown in Table 5) with the interfacial property of $\mathrm{Al} / \mathrm{Al}_{3}(\mathrm{Zr}, \mathrm{Sc}$ ) (shown in Table 6). 
Table 6. Griffith separation work of interface models with different Sc-doped sites and Sc-doping ratios.

\begin{tabular}{|c|c|c|c|c|c|}
\hline Model & $W \operatorname{ad}\left(\mathrm{J} / \mathrm{m}^{2}\right)$ & Model & $W \mathrm{ad}\left(\mathrm{J} / \mathrm{m}^{2}\right)$ & Model & Wad $\left(\mathrm{J} / \mathrm{m}^{2}\right)$ \\
\hline $\mathrm{Al} / \mathrm{Al}_{3} \mathrm{Zr}(\mathrm{Sc} 1-1)$ (I-ter) & 3.108 & $\mathrm{Al} / \mathrm{Al}_{3} \mathrm{Zr}(\mathrm{Sc} 2-1)$ (I-ter) & 2.998 & $\mathrm{Al} / \mathrm{Al}_{3} \mathrm{Zr}(\mathrm{Sc} 3-1)$ (I-ter) & 3.008 \\
\hline $\mathrm{Al} / \mathrm{Al}_{3} \mathrm{Zr}(\mathrm{Sc} 1-2)$ (I-ter) & 2.996 & $\mathrm{Al} / \mathrm{Al}_{3} \mathrm{Zr}(\mathrm{Sc} 2-2)$ (I-ter) & 3.000 & $\mathrm{Al} / \mathrm{Al}_{3} \mathrm{Zr}(\mathrm{Sc} 3-2)$ (I-ter) & 3.014 \\
\hline $\mathrm{Al} / \mathrm{Al}_{3} \mathrm{Zr}(\mathrm{Sc} 1-3)$ (I-ter) & 3.022 & $\mathrm{Al} / \mathrm{Al}_{3} \mathrm{Zr}(\mathrm{Sc} 2-3)$ (I-ter) & 3.021 & $\mathrm{Al} / \mathrm{Al}_{3} \mathrm{Zr}(\mathrm{Sc} 3-3)$ (I-ter) & 3.021 \\
\hline $\mathrm{Al} / \mathrm{Al}_{3} \mathrm{Zr}(\mathrm{Sc} 1-1)$ (D-ter) & 2.501 & $\mathrm{Al} / \mathrm{Al}_{3} \mathrm{Zr}(\mathrm{Sc} 2-1)$ (D-ter) & 2.502 & $\mathrm{Al} / \mathrm{Al}_{3} \mathrm{Zr}(\mathrm{Sc} 3-1)$ (D-ter) & 2.498 \\
\hline $\mathrm{Al} / \mathrm{Al}_{3} \mathrm{Zr}(\mathrm{Sc} 1-2)$ (D-ter) & 2.825 & $\mathrm{Al} / \mathrm{Al}_{3} \mathrm{Zr}(\mathrm{Sc} 2-2)$ (D-ter) & 2.532 & $\mathrm{Al} / \mathrm{Al}_{3} \mathrm{Zr}(\mathrm{Sc} 3-2)$ (D-ter) & 2.485 \\
\hline $\mathrm{Al} / \mathrm{Al}_{3} \mathrm{Zr}(\mathrm{Sc} 1-3)$ (D-ter) & 2.829 & $\mathrm{Al} / \mathrm{Al}_{3} \mathrm{Zr}(\mathrm{Sc} 2-3)$ (D-ter) & 2.886 & $\mathrm{Al} / \mathrm{Al}_{3} \mathrm{Zr}(\mathrm{Sc} 3-3)$ (D-ter) & 2.503 \\
\hline
\end{tabular}

\subsection{Electronic Structure}

\subsubsection{Density of States}

For a deeper insight into the electron interaction and the atomic bonding, the partial density of states (PDOS) of the four intermetallics $\mathrm{Al}_{3} \mathrm{TM}(\mathrm{TM}=\mathrm{Ti}, \mathrm{Zr}, \mathrm{Hf}, \mathrm{Sc})$ are shown in Figure 6 . The dashed line represents the Fermi level. Figure 6 shows that the bonding between $\mathrm{Al}-\mathrm{TM}$ atoms in the $\mathrm{Al}_{3} \mathrm{TM}$ block is mainly metallic bonding due to numerous valence electrons at the Fermi energy level $E_{\mathrm{F}}$. In $\mathrm{Al}_{3} \mathrm{Zr}$, a broad overlap between $\mathrm{Zr}$ and $\mathrm{Al}$ valence electrons below $E_{\mathrm{F}}$ indicates that covalent bonding exists between $\mathrm{Al}-\mathrm{Zr}$ atoms. This means that the binding strength for $\mathrm{Al}_{3} \mathrm{Zr}$ is mainly dominated by metallic bonding, while an influence of covalent bonding between $\mathrm{Al}-\mathrm{Zr}$ atoms cannot be ignored besides metallic bonding. The PDOS of the other $\mathrm{Al}_{3} \mathrm{TM}(\mathrm{Ti}, \mathrm{Hf}, \mathrm{Sc})$ phases shows that the electronic interaction between $\mathrm{Al}-\mathrm{TM}(\mathrm{Ti}, \mathrm{Hf}, \mathrm{Sc})$ is also mixed with metallic and covalent bonding. However, compared with $\mathrm{Al}_{3} \mathrm{Zr}$, the overlap between $\mathrm{TM}(\mathrm{Ti}, \mathrm{Hf}, \mathrm{Sc})$ and $\mathrm{Al}$ valence electrons below $E_{\mathrm{F}}$ is weaker than $\mathrm{Zr}$-Al atoms at different degrees, which provides an explanation for the higher binding energy of $\mathrm{Al}_{3} \mathrm{Zr}$ shown in Table 2.
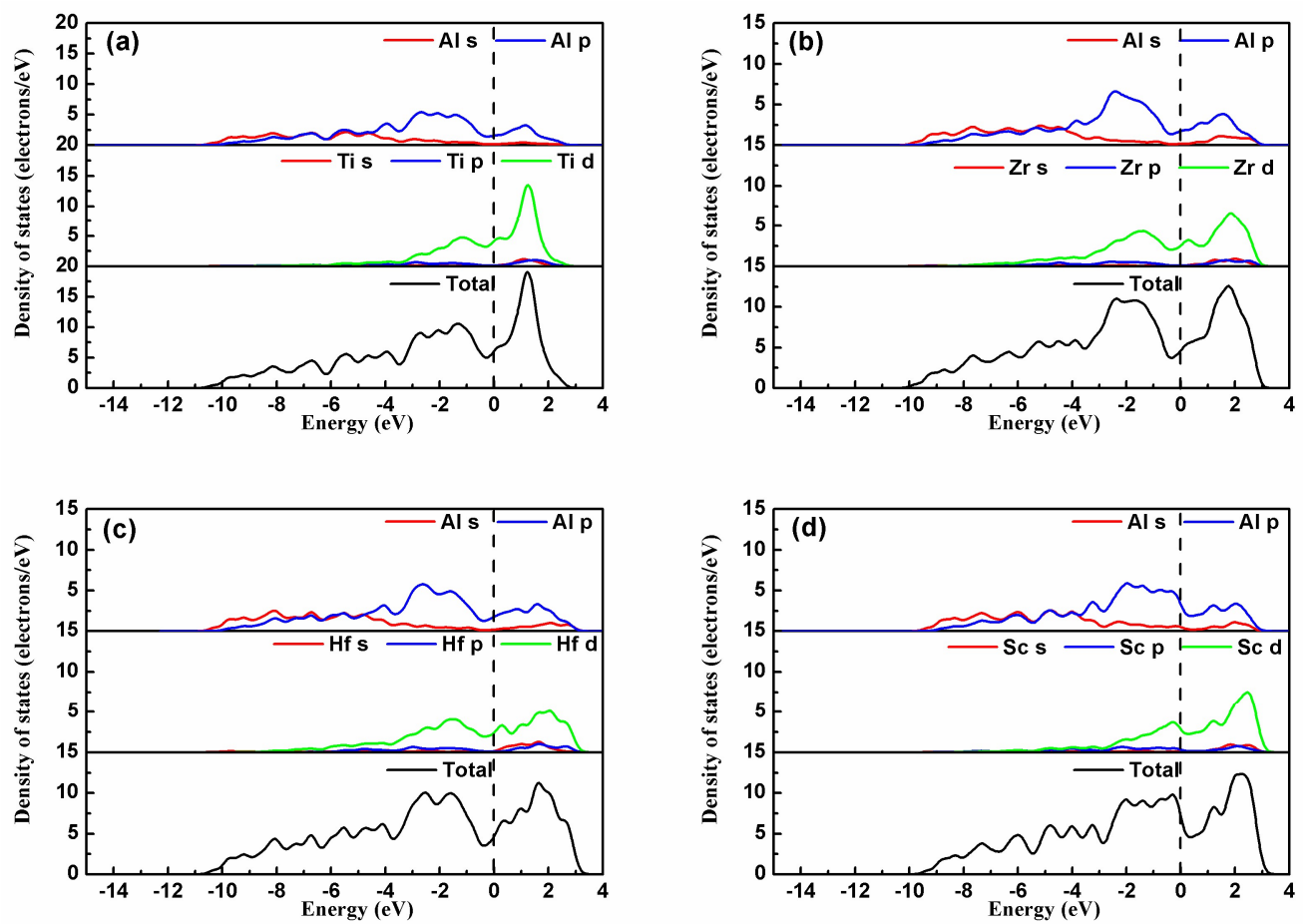

Figure 6. The partial density of states of (a) $\mathrm{Al}_{3} \mathrm{Ti}$, (b) $\mathrm{Al}_{3} \mathrm{Zr}$, (c) $\mathrm{Al}_{3} \mathrm{Hf}$, and (d) $\mathrm{Al}_{3} \mathrm{Sc}$. 


\subsubsection{Planar-Averaged Difference Charge}

Planar-averaged difference charge (relative to the isolated surfaces) for the interface models with different doping ratios and doping sites is shown in Figure 7. Planar-averaged charge is obtained by adding the total electron density in the same atomic layer. Planar-averaged difference charge can be calculated by using Equation (16).

$$
\Delta \rho=\rho_{\mathrm{Al}-\mathrm{Al}}(\mathrm{Zr}, \mathrm{Sc})-\rho_{\mathrm{Al}}-\rho_{\mathrm{Al}_{3}(\mathrm{Zr}, \mathrm{Sc})}
$$

Here, $\rho_{\mathrm{Al}-\mathrm{Al}_{3}(\mathrm{Zr} \text {, Sc) }}$ presents the total electron density of interface model, $\rho_{\mathrm{Al}}$ is the total electron density of only $\mathrm{Al}$ matrix with the $\mathrm{Al}_{3}(\mathrm{Zr}, \mathrm{Sc})$ in the former interface substituted with vacuum, and $\rho_{\mathrm{Al}_{3}(\mathrm{Zr}, \mathrm{Sc})}$ represents the total electron density of only $\mathrm{Al}_{3}(\mathrm{Zr}, \mathrm{Sc})$ with the $\mathrm{Al}$ matrix in the former interface substituted with vacuum. To ensure the same points of electron density values are obtained, the same cutoff energy and $k$-points must be set during the calculation process.

The planar-averaged charge density shows that the charge transfers around the interface between the $\mathrm{Al}$ matrix and $\mathrm{Al}_{3} \mathrm{TM}$, which is shown in Figure 7. Furthermore, the charge transfer affects the electron distribution of the atoms in two to three layers extending into both sides from the interface. It is clearly shown in Figure 7 that the atoms near the D-ter interfaces move away from their original sites in the interface and bring in lattice distortion. But the atoms in the I-ter interfaces keep the original lattice positions and cause little distortion. So, the interface with I-ter can maintain a better coherent lattice relationship and results in a lower interfacial energy, which makes the I-ter interface more likely to form and explains the inner reason for the results discussed in Section 3.3. Overall, the localization of charge transfer of the $\mathrm{Al} / \mathrm{Al}_{3} \mathrm{Zr}$ (I-ter) interface is clearer than that of the $\mathrm{Al} / \mathrm{Al}_{3} \mathrm{Zr}$ (D-ter) interface, which shows a higher interface bonding strength. Additionally, the charge transfer distribution in the $\mathrm{Al} / \mathrm{Al}_{3} \mathrm{Zr}$ (I-ter) interface model broadens and affects the electron distribution around the inner atoms extending to both sides, which results in more stable I-ter interfaces with higher Griffith rupture work.

Figure $7 \mathrm{~b}$ shows that the doped $\mathrm{Sc}$ atoms increase the interfacial interaction shown by the planar-averaged difference charge. However, the charge transfer of $\mathrm{Al} / \mathrm{Al}_{3} \mathrm{Zr}$ (Sc2-1) (I-ter) and $\mathrm{Al} / \mathrm{Al}_{3} \mathrm{Zr}$ (Sc3-1) (I-ter) shows little difference from that of $\mathrm{Al} / \mathrm{Al}_{3} \mathrm{Zr}$ (Sc1-1) (I-ter). It can be concluded that on the condition that the ratio of Sc: $\mathrm{Zr}$ reaches 1:3, after the $\mathrm{Al}_{3} \mathrm{Sc}(\mathrm{Zr}, \mathrm{Sc}): \mathrm{Zr}$ reaches the 1:3 proportion, further increasing of the ratio of $S c: Z r$ is fruitless for improving the interface bonding strength. In addition, as long as the $\mathrm{Zr}$ atom adjacent to the interface is replaced with $\mathrm{Sc}$, the atomic lattices are all coherent with the Al matrix. This is consistent with the results of Griffith rupture work shown in Table 6.

Valence charge density is averaged on each (001) plane. The supercell containing 12 layers of $\mathrm{Al}_{3}(\mathrm{Zr}, \mathrm{Sc})$ and eight layers of $\mathrm{Al}$ with a vacuum region is shown. Red circle, blue triangle, and solid green circle indicate the positions of $\mathrm{Al}, \mathrm{Zr}$, and $\mathrm{Sc}$ in atomic layers, respectively. The interface is marked by a vertical line.
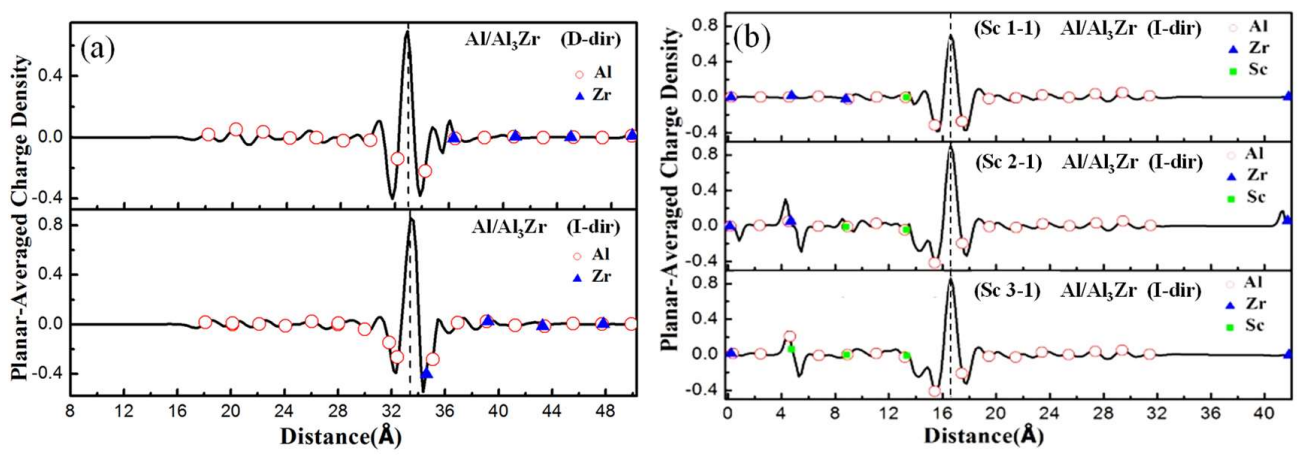

Figure 7. Planar-averaged differential electron density. (a) $\mathrm{Al} / \mathrm{Al}_{3} \mathrm{Zr}$ interfaces with $\mathrm{D}$-ter and I-ter, (b) $\mathrm{Al} / \mathrm{Al}_{3}(\mathrm{Zr}, \mathrm{Sc})$ interfaces with different $\mathrm{Sc}$-doping ratio. 


\section{Conclusions}

In summary, we have explored the energy, elastic properties, and electronic structure of $\mathrm{Al}_{3} \mathrm{TM}(\mathrm{TM}=\mathrm{Ti}, \mathrm{Zr}, \mathrm{Hf}, \mathrm{Sc})$ and $\mathrm{Al}_{3}(\mathrm{Zr}, \mathrm{Sc})$. Besides, the interfacial properties of $\mathrm{Al}_{1} \mathrm{Al}_{3} \mathrm{TM}(\mathrm{TM}=\mathrm{Ti}, \mathrm{Zr}$, $\mathrm{Hf}, \mathrm{Sc})$ and $\mathrm{Al} / \mathrm{Al}_{3}(\mathrm{Zr}, \mathrm{Sc})$ have also been investigated by first-principle simulations. $\mathrm{Al}_{3}(\mathrm{Zr}, \mathrm{Sc})$ with the ratio of Sc:Zr at 1:3 shows the highest absolute value of formation enthalpy, which means that it is the most suitable for use as a grain refiner among all the intermetallics. According to elastic properties and their anisotropy characteristics, Sc-doped $\mathrm{Al}_{3}(\mathrm{Zr}, \mathrm{Sc})$ shows a more beneficial isotropy than $\mathrm{Al}_{3} \mathrm{Sc}$.

Comparing interfaces with two different terminals, $\mathrm{Al} / \mathrm{Al}_{3} \mathrm{TM}$ interfaces with I-ter modes are more stable than $\mathrm{Al} / \mathrm{Al}_{3} \mathrm{TM}$ interfaces with $\mathrm{D}$-ter modes, because $\mathrm{Al} / \mathrm{Al}_{3} \mathrm{TM}$ interfaces with I-ter modes overall show larger Griffith rupture work and a smaller interface energy than $\mathrm{Al}_{1} / \mathrm{Al}_{3} \mathrm{TM}$ interfaces with D-ter modes. Among all the $\mathrm{Al} / \mathrm{Al}_{3} \mathrm{TM}(\mathrm{TM}=\mathrm{Ti}, \mathrm{Zr}, \mathrm{Hf}, \mathrm{Sc})$ interfacial modes, the $\mathrm{Al} / \mathrm{Al}_{3} \mathrm{Sc}$ interface shows the highest Griffith rupture work and lowest interfacial energy, which indicates that $\mathrm{Sc}$ atoms should get priority for occupying interfacial sites. What is more, the binding strength of $\mathrm{Al}_{3} \mathrm{Zr}$ with the $\mathrm{Al}$ matrix can effectively be improved by Sc-doping.

Acknowledgments: This work was financially supported by the National Natural Science Foundation of China (No. 51601153), Chongqing research program of basic research and frontier technology (No. cstc2017jcyjAX0195), and the Fundamental Research Funds for the Central Universities (No. SWU115068 and No. XDJK2018C004).

Author Contributions: Chunmei Li and Zhiqian Chen conceived and designed the research programme; Zhongjing Xie performed the calculations; Chunmei Li and Nanpu Cheng analyzed the data; Liangliang Hui built computational models; Chunmei Li wrote the paper.

Conflicts of Interest: The authors declare no conflicts of interest.

\section{References}

1. Dinaharan, I.; Kumar, G.A.; Vijay, S.J.; Murugan, N. Development of $\mathrm{Al}_{3} \mathrm{Ti}$ and $\mathrm{Al}_{3} \mathrm{Zr}$ intermetallic particulate reinforced aluminum alloy AA6061 in situ composites using friction stir processing. Mater. Design 2014, 63, 213-222. [CrossRef]

2. Zheng, Q.; Yang, C.; Wang, S.; Yu, A.; Chen, H.; He, Y. Effect of compound inoculants Ti and Zr on as cast microstructure and mechanical properties of Al-Cu alloy. Mater. Res. Innov. 2014, 18, 59-63. [CrossRef]

3. Duan, Y.L.; Xu, G.F.; Tang, L.; Liu, Y.; Xu, J.W.; Deng, Y.; Yin, Z.M. Excellent high strain rate superplasticity of Al-Mg-Sc-Zr alloy sheet produced by an improved asymmetrical rolling process. J. Alloys Compd. 2017, 715, 311-321. [CrossRef]

4. $\quad$ Deng, Y.; Yin, Z.M.; Pan, Q.L.; Xu, G.F.; Duan, Y.L.; Wang, Y.J. Nano-structure evolution of secondary $\mathrm{Al}_{3}\left(\mathrm{Sc}_{1-\mathrm{x}} \mathrm{Zr}_{\mathrm{x}}\right)$ particles during superplastic deformation and their effects on deformation mechanism in Al-Zn-Mg alloys. J. Alloys Compd. 2017, 695, 142-153. [CrossRef]

5. Sun, F.F.; Nash, G.L.; Li, Q.Y.; Liu, E.Z.; He, C.N.; Shi, C.S.; Zhao, N.Q. Effect of Sc and Zr additions on microstructures and corrosion behavior of Al-Cu-Mg-Sc-Zr alloys. J. Mater. Sci. Technol. 2017, 33, 1015-1022. [CrossRef]

6. Li, C.M.; Zeng, S.M.; Chen, Z.Q.; Cheng, N.P.; Chen, T.X. First-principles calculations of elastic and thermodynamic properties of the four main intermetallic phases in Al-Zn-Mg-Cu alloys. Comput. Mater. Sci. 2014, 93, 210-220. [CrossRef]

7. Boulechfar, R.; Meradji, H.; Ghemid, S.; Drablia, S.; Bouhafs, B. First principle calculations of structural, electronic and thermodynamic properties of $\mathrm{Al}_{3}(\mathrm{TixV1-x})$ alloy in D0 and $\mathrm{L} 1$ structures. Solid. State. Sci. 2013, 16, 1-5. [CrossRef]

8. Yuan, X.L.; Wei, D.Q.; Cheng, Y.; Ji, G.F.; Zhang, Q.M.; Gong, Z.Z. Pressure effects on elastic and thermodynamic properties of $\mathrm{Zr}_{3} \mathrm{Al}$ intermetallic compound. Comput. Mater. Sci. 2012, 58, 125-130. [CrossRef]

9. Ghosh, G.; van de Walle, A.; Asta, M. First-principles calculations of the structural and thermodynamic properties of bcc, fcc and hcp solid solutions in the Al-TM (TM = Ti, Zr and Hf) systems: A comparison of cluster expansion and supercell methods. Acta Mater. 2008, 56, 3202-3221. [CrossRef]

10. Li, J.; Yang, Y.Q.; Luo, X. First-principles study of the $\mathrm{Al}(001) / \mathrm{Al}_{3} \mathrm{Ti}(001)$ interfacial properties. Comput. Mater. Sci. 2012, 62, 136-141. [CrossRef] 
11. Asta, M.; Foiles, S.M.; Quong, A.A. First-principles calculations of bulk and interfacial thermodynamic properties for fcc-based Al-Sc alloys. Phys. Rev. B 1998, 57, 11265-11275. [CrossRef]

12. Li, J.; Zhang, M.; Zhou, Y.; Chen, G.X. First-principles study of Al/ $\mathrm{A}_{3}$ Ti heterogeneous nucleation interface. Appl. Surf. Sci. 2014, 307, 593-600. [CrossRef]

13. Colinet, C.; Pasturel, A. Ab initio calculation of the formation energies of L1, D0, D0 and one dimensional long period structures in TiAl3 compound. Intermetallics 2002, 10, 751-764. [CrossRef]

14. Amador, C.; Hoyt, J.J.; Chakoumakos, B.C.; Defontaine, D. Theoretical and Experimental-Study of Relaxations in $\mathrm{Al}_{3}$ ti and $\mathrm{Al}_{3} \mathrm{Zr}$ Ordered Phases. Phys. Rev. Lett. 1995, 74, 4955-4958. [CrossRef] [PubMed]

15. Srinivasan, S.; Desch, P.B.; Schwarz, R.B. Metastable Phases in the $\mathrm{Al}_{3} \mathrm{X}(\mathrm{X}=\mathrm{Ti}, \mathrm{Zr}$, and Hf) Intermetallic System. Scripta. Metall. Mater. 1991, 25, 2513-2516. [CrossRef]

16. Liu, Z.L.; Qiu, D.; Wang, F.; Taylor, J.A.; Zhang, M.X. The grain refining mechanism of cast zinc through silver inoculation. Acta. Mater. 2014, 79, 315-326. [CrossRef]

17. Ghosh, G.; Asta, M. First-principles calculation of structural energetics of Al-TM (TM = Ti, Zr, Hf) intermetallics. Acta Mater. 2005, 53, 3225-3252. [CrossRef]

18. Colinet, C.; Pasturel, A. Phase stability and electronic structure in $\mathrm{ZrAl}_{3}$ compound. J. Alloys. Compd. 2001, 319, 154-161. [CrossRef]

19. Kematick, R.J.; Franzen, H.F. Thermodynamic Study of the Zirconium Aluminum System. J. Solid State Chem. 1984, 54, 226-234. [CrossRef]

20. Ma, Y.; Rømming, C.; Lebech, B.; Gjønnes, J.; Taftø, J. Structure refinement of $\mathrm{Al}_{3} \mathrm{Zr}$ using single-crystal X-ray diffraction, powder neutron diffraction and CBED. Acta Crystallogr. 2010, 48, 11-16. [CrossRef]

21. Colinet, C.; Pasturel, A. Phase stability and electronic structure of the compound. Phys. Rev. B 2001, 64, 197-201. [CrossRef]

22. Vanderbilt, D.; Louie, S.G. Total energies of diamond (111) surface reconstructions by a linear combination of atomic orbitals method. Phys. Rev. B 1984, 30, 6118-6130. [CrossRef]

23. Perdew, J.P.; Chevary, J.A.; Vosko, S.H.; Jackson, K.A.; Pederson, M.R.; Singh, D.J.; Fiolhais, C. Atoms, molecules, solids, and surfaces: Applications of the generalized gradient approximation for exchange and correlation. Phys. Rev. B 1992, 46, 6671-6887. [CrossRef]

24. Perdew, J.P.; Burke, K.; Ernzerhof, M. ERRATA:Generalized gradient approximation made simple. Phys. Rev. Lett. 1996, 77, 3865-3868. [CrossRef] [PubMed]

25. Monkhorst, H.J.; Pack, J.D. Special Points for Brillonin-Zone Integrations. Phys. Rev. B 1976, 13, 5188. [CrossRef]

26. Fischer, T.H.; Almlof, J. General methods for geometry and wave function optimization. J. Phys. Chem. 1992, 96, 9768-9774. [CrossRef]

27. Medvedeva, N.I.; Gornostyrev, Y.N.; Novikov, D.L.; Mryasov, O.N.; Freeman, A.J. Ternary site preference energies, size misfits and solid solution hardening in NiAl and FeAl. Acta Mater. 1998, 46, 3433-3442. [CrossRef]

28. Chunmei, L.I.; Chen, Z.Q.; Zeng, S.M.; Cheng, N.P.; Chen, T.X. Intermetallic phase formation and evolution during homogenization and solution in Al-Zn-Mg-Cu alloys. Sci. China Tech. Sci. 2013, 56, 2827-2838.

29. Deyirmenjian, V.B.; Heine, V.V.; Payne, M.C.; Milman, V.V.; Lyndenbell, R.M.; Finnis, M.W. Ab initio atomistic simulation of the strength of defective aluminum and tests of empirical force models. Phys. Rev. B 1995, 52, 15191-15207. [CrossRef]

30. Milman, V.; Warren, M.C. Elastic properties of $\mathrm{TiB}_{2}$ and $\mathrm{MgB}_{2}$. J. Phys. Condens. Matter 2001, 13, 5585-5595. [CrossRef]

31. Aydin, S.; Simsek, M. First-principles calculations of elemental crystalline boron phases under high pressure: Orthorhombic B28 and tetragonal B48. J. Alloy Compd. 2011, 509, 5219-5229. [CrossRef]

32. Duan, Y.H.; Sun, Y.; Guo, Z.Z.; Peng, M.J.; Zhu, P.X.; He, J.H. Elastic constants of $\mathrm{AlB}_{2}$-type compounds from first-principles calculations. Comput. Mater. Sci. 2012, 51, 112-116. [CrossRef]

33. Hashibon, A.; Elsässer, C.; Mishin, Y.; Gumbsch, P. First-principles study of thermodynamical and mechanical stabilities of thin copper film on tantalum. Phys. Rev. B 2007, 76, 4692. [CrossRef]

34. Cacciamani, G.; Riani, P.; Borzone, G.; Parodi, N.; Saccone, A.; Ferro, R.; Pisch, A.; Schmid-Fetzer, R. Thermodynamic measurements and assessment of the Al-Sc system. Intermetallics 1999, 7, 101-108. [CrossRef] 
35. Fu, C.L. Electronic, elastic, and fracture properties of trialuminide alloys: $\mathrm{Al}_{3} \mathrm{Sc}$ and $\mathrm{Al}_{3}$ Ti. J. Mater. Res. 1990, 5, 971-979. [CrossRef]

36. Asta, M.; De, F.D.; Van, S.M.; Sluiter, M.; Methfessel, M. First-principles phase-stability study of fcc alloys in the Ti-Al system. Phys. Rev. B 1992, 46, 5055-5072. [CrossRef]

37. Watson, R.E.; Weinert, M. Transition-metal aluminide formation: Ti, V, Fe, and Ni aluminides. Phys. Rev. B 1998, 58, 5981-5988. [CrossRef]

38. Nassik, M.; Chrifi-Alaoui, F.Z.; Mahdouk, K.; Gachon, J.C. Calorimetric study of the aluminium-titanium system. J. Alloy Compd. 2003, 350, 151-154. [CrossRef]

39. Clouet, E.; Sanchez, J.; Sigli, C. First principles study of the solubility of Zr in Al. Phys. Rev. B 2012, 65, 094105. [CrossRef]

40. Murray, J.; Peruzzi, A.; Abriata, J.P. The Al-Zr (aluminum-zirconium) system. J. Phase Equilib. 1992, 13, 277-291. [CrossRef]

41. Meschel, S.V.; Kleppa, O.J. Standard enthalpies of formation of $4 \mathrm{~d}$ aluminides by direct synthesis calorimetry. J. Alloy Compd. 1993, 191, 111-116. [CrossRef]

42. Meschel, S.V.; Kleppa, O.J. Standard enthalpies of formation of $5 \mathrm{~d}$ aluminides by high-temperature direct synthesis calorimetry. J. Alloy Compd. 1993, 197, 75-81. [CrossRef]

43. Balducci, G.; Ciccioli, A.; Gigli, G.; Gozzi, D.; Anselmi-Tamburini, U. Thermodynamic study of intermetallic phases in the Hf-Al system. J. Alloy Compd. 1995, 220, 117-121. [CrossRef]

44. Pugh, S.F.; XCII. Relations between the elastic moduli and the plastic properties of polycrystalline pure metals. Philos. Mag. 1954, 45, 823-843. [CrossRef]

45. Boulechfar, R.; Ghemid, S.; Meradji, H.; Bouhafs, B. FP-LAPW investigation of structural, electronic, and thermodynamic properties of $\mathrm{Al}_{3} \mathrm{~V}$ and $\mathrm{Al}_{3} \mathrm{Ti}$ compounds. Physica B 2010, 405, 4045-4050. [CrossRef]

46. Wang, J.; Shang, S.L.; Wang, Y. First-principles calculations of binary Al compounds: Enthalpies of formation and elastic properties. Calphad 2011, 35, 562-573. [CrossRef]

47. Nakamura, M.; Kimura, K. Elastic constants of $\mathrm{TiAl}_{3}$, and $\mathrm{ZrAl}_{3}$, single crystals. J. Mater. Sci. 1991, 26, 2208-2214. [CrossRef]

48. Mao, Z.; Chen, W.; Seidman, D.N. First-principles study of the nucleation and stability of ordered precipitates in ternary Al-Sc-Li alloys. Acta Mater. 2011, 59, 3012-3023. [CrossRef]

49. Hasegawa, M.; Yagi, T. Systematic study of formation and crystal structure of 3d-transition metal nitrides synthesized in a supercritical nitrogen fluid under $10 \mathrm{GPa}$ and $1800 \mathrm{~K}$ using diamond anvil cell and YAG laser heating. J. Alloys Compd. 2005, 403, 131-142. [CrossRef]

50. Nye, F. Physical Properties of Crystals; Clarendon Press: Oxford, UK, 1964; pp. 145-146.

51. Yin, D.Q.; Yang, Y.; Peng, X.H.; Qin, Y.; Wang, Z.C. Tensile and fracture process of the TiN/VN interface from first principles. Ceram. Int. 2014, 40, 14453-14462. [CrossRef]

52. Ouyang, G.; Tan, X.; Wang, C.X. Charge-induced transition between miscible and immiscible in nanometer-sized alloying particles. Chem. Phys. Lett. 2006, 420, 65-70. [CrossRef]

53. Li, J.H.; Oberdorfer, B.; Wurster, S.; Schumacher, P. Samenvatting Impurity effects on the nucleation and growth of primary $\mathrm{Al}_{3}(\mathrm{Sc}, \mathrm{Zr})$ phase in $\mathrm{Al}$ alloys. J. Mater. Sci. 2014, 49, 5961-5977. [CrossRef]

54. Radmilovic, V.; Tolley, A.; Dahmen, U. HREM and HAADF Imaging of $\mathrm{Al}_{3}(\mathrm{Sc}, \mathrm{Zr})$ Core/Shell Structure. Microsc. Microanal. 2005, 11, 1712-1713. [CrossRef]

(C) 2018 by the authors. Licensee MDPI, Basel, Switzerland. This article is an open access article distributed under the terms and conditions of the Creative Commons Attribution (CC BY) license (http:// creativecommons.org/licenses/by/4.0/). 